\title{
A new species of Craugastor (Anura: Craugastoridae) from the montane rainforest of the Cordillera de Talamanca, Costa Rica
}

\author{
Erick Arias, ${ }^{1,2}$ Gerardo Chaves, ${ }^{2}$ and Gabriela Parra-Olea ${ }^{1}$ \\ ${ }^{1}$ Departamento de Zoología, Instituto de Biología, UNAM, AP 70-153, Ciudad Universitaria, CP 04510, Ciudad de México, \\ Mexico. E-mail: gparra@ib.unam.mx. \\ ${ }^{2}$ Escuela de Biología, Universidad de Costa Rica, San Pedro, 11501-2060, San José, Costa Rica.
}

\begin{abstract}
A new species of Craugastor (Anura: Craugastoridae) from the montane rainforest of the Cordillera de Talamanca, Costa Rica. A new dirt frog of the Craugastor podiciferus Species Group is described from Costa Rica; it is restricted to elevations between 2330 and $2700 \mathrm{~m}$ a.s.l. in the montane rainforest of the Cordillera de Talamanca. Analysis of DNA sequences of the mitochondrial 16S rRNA (16S) and cytochrome oxidase I (COI) genes reveals a distinct lineage within the $C$. podiciferus Species Group. Additional morphological and morphometric analyses support the distinctiveness of this lineage that is described as a new species herein. The species is distinguished from other members of the $C$. podiciferus Species Group by its unique coloration: a violet-brown to blackish brown venter with white pigment forming blotches, and dark brown palmar surfaces with prominent white folds between subarticular tubercles in the adults. The genetic divergence of the species from other members of the $C$. podiciferus Species Group is significant (higher than $9.2 \%$ in $16 \mathrm{~S}$ and $13.3 \%$ in $\mathrm{COI}$ ). Although not closely related, it resembles C. podiciferus morphologically, a species that also inhabits montane rainforest. The discovery of this new species highlights the importance of montane rainforest as a center of species richness and endemism.
\end{abstract}

Keywords: Brachycephaloidea, Central America, Craugastor podiciferus Species Group, Panama, Terrarana.

\section{Resumen}

Una especie nueva de Craugastor (Anura: Craugastoridae) del bosque montano lluvioso en la Cordillera de Talamanca, Costa Rica. Se describe una especie nueva para Costa Rica de rana de hojarasca perteneciente al grupo de especies Craugastor podiciferus, restringida a elevaciones entre 2330-2700 m s.n.m. en el bosque montano lluvioso de la Cordillera de Talamanca. Análisis de las secuencias del ADN de los genes mitocondriales $16 \mathrm{~S}$ ARNr (16S) y citocromo oxidasa 1 (COI) reveló un linaje distinto dentro del grupo de especies C. podiciferus. Los análisis complementarios

Received 18 June 2018

Accepted 27 November 2018

Distributed December 2018 
de morfología y morfometría apoyaron la diferenciación de este linaje, el cual describimos aquí como una especie nueva. Esta especie se distingue de los miembros del grupo de especies $C$. podiciferus por su coloración única: vientre violeta-marrón a marrón negruzco con pigmento blanco formando manchas, la superficie palmar en adultos es marrón oscuro con pliegues blancos prominentes entre los tubérculos subarticulares. Geneticamente esta nueva especie es significativamente divergente de los demás miembros del grupo de especies C. podiciferus (mayores a 9.3\% en el $16 \mathrm{~S}$ y $13.3 \%$ en COI). Aunque no están estrechamente relacionadas, la nueva especie es morfológicamente similar a C. podiciferus, especie que también habita en el bosque montano lluvioso. El descubrimiento de esta nueva especie resalta la importancia del bosque montano lluvioso como un centro de riqueza de especies y endemismos.

Palabras clave: América Central, Brachycephaloidea, grupo de especies Craugastor podiciferus, Panamá, Terrarana.

\begin{abstract}
Resumo
Uma nova espécie de Craugastor (Anura: Craugastoridae) do bosque montano chuvoso da Cordilheira de Talamanca, Costa Rica. Descrevemos aqui uma nova espécie do grupo de Craugastor podiciferus para a Costa Rica, restrita a altitudes entre 2330-2700 m acima do nível do mar no bosque montano chuvoso da Cordilheira de Talamanca. Análises das sequências de DNA dos genes mitocondriais16S ARNr (16S) e da citocromo oxidase 1 (COI) revelaram uma linhagem distinta dentro do grupo de espécies de $C$. podiciferus. Análises morfológicas e morfométricas complementares apoiaram a diferenciação desta linhagem, que descrevemos aqui como uma espécie nova. Essa espécie distingue-se dos membros do grupo de espécies de $C$. podiciferus por sua coloração única: ventre marrom-violeta a marrom enegrecido com pigmento branco formando manchas e superfície palmar nos adultos marrom escura com pregas brancas proeminentes entre os tubérculos sub-articulares. Geneticamente esta nova espécie é significativamente divergente dos demais membros do grupo de espécies de C. podiciferus (maiores em $9.3 \%$ no $16 \mathrm{~S}$ e $13.3 \%$ no COI). Ainda que não estejam estreitamente relacionadas, a nova espécie é morfologicamente similar a $C$. podiciferus, que também habita o bosque montano chuvoso. A descoberta dessa nova espécie ressalta a importância do bosque montano chuvoso como um centro de riqueza de espécies e endemismos.
\end{abstract}

Palavras-chave: América Central, Brachycephaloidea, grupo de espécies de Craugastor podiciferus, Panamá, Terrarana.

\section{Introduction}

The highlands of isthmian Central America are characterized by a high level of species richness and endemism. The isthmian highlands (1000-3820 $\mathrm{m}$ a.s.l.) are an isolated topographic unit in Central America (Campbell 1999, Gutiérrez-García and Vázquez-Domínguez 2013) formed by the Guanacaste, Tilarán, Central, and Talamanca mountain ranges. The Cordillera de Talamanca extends from the central valley in Costa Rica to western Panama and contains both the highest mountain peaks of the isthmus (Campbell 1999, Savage 2002) and the most endemic amphibians of Costa Rica (Campbell
1999, Olson et al. 2001, Savage 2002, BozaOviedo et al. 2012). The summits of the Cordillera de Talamanca (ranging from 2500$3500 \mathrm{~m}$ a.s.l.) are dominated by Montane Rainforest Life Zone (Holdridge 1967, Bolaños et al. 2005), which is extremely fragmented and isolated. The Talamanca montane rainforest (TMR) is relatively poorly studied and is thought to have a lower species diversity than the premontane forest of Talamanca Range (Kubicki 2008, Santos-Barrera et al. 2008, Arias and Bolaños 2014). Nevertheless, the TMR is home to several micro endemic amphibians-viz. Atelopus chirripoensis Savage and Bolaños, 2009, Bolitoglossa kamuk Boza-Oviedo, Rovito, 
Chaves, García-Rodríguez, Artavia, Bolaños, and Wake, 2012, B. pesrubra Taylor, 1952, B. pygmaea Bolaños and Wake, 2009, B. robinsoni Bolaños and Wake, 2009, B. splendida BozaOviedo, Rovito, Chaves, García-Rodríguez, Artavia, Bolaños, and Wake, 2012, and Diasporus ventrimaculatus Chaves, GarcíaRodríguez, Mora, and Leal, 2009.

During recent fieldwork in the TMR we found frogs of the Craugastor podiciferus Species Group Hedges et al. (2008). The anurans were collected at the summits of Cerro Arbolado, Cerro Hakú, Cerro Utyum, and Caribbean slopes of Cerro Pando. The population of Cerro Utyum is near ( $10 \mathrm{~km}$ airline distance) to the type locality of $C$. podiciferus (Cope, 1875) (Cope 1875, Arias and Chaves 2014) and both species of anurans are morphologically similar. Craugastor podiciferus is abundant, with a broad distribution across the highlands of all the mountain ranges of Costa Rica and western Panama (1000-2650 $\mathrm{m}$ a.s.1.); it has been thought to represent a species complex with several unnamed species (Savage 2002, Streicher et al. 2009). Molecular analyses of two mitochondrial genes showed that despite the morphological resemblance to $C$. podiciferus, the recently discovered populations from the TMR are not $C$. podiciferus, but instead represent a new member of the species group, which is described here based on molecular and morphological data.

\section{Materials and Methods}

\section{Taxon Sampling}

Frogs of the new species were collected at five localities along the Cordillera de Talamanca, at the summits of Cerro Arbolado, Cerro Hakú, Cerro Utyum, and the Caribbean slopes of Cerro Pando in southwestern Costa Rica (Figure 1). In addition, we collected several specimens from highlands of Costa Rica and western Panama, including several populations referred to $C$. podiciferus, Craugastor sp.B of Crawford \& Smith (2005), and two populations that we record herein as unnamed species (Craugastor sp.1 and Craugastor sp.2). The frogs were euthanized in the field and extracted liver or muscle tissue was preserved in $95 \%$ ethanol or RNAlater. Voucher specimens were fixed in $10 \%$ formalin, stored in $70 \%$ ethanol, and deposited at the Museo de Zoología, Universidad de Costa Rica (UCR) and Senckenberg Research Institute and Nature Museum, Frankfurt, Germany (SMF). Museum codes follow those of Frost (2018), with the addition of CRARC in reference to the Costa Rica Amphibian Research Center private collection; EAP denotes field numbers of Erick Arias.

\section{Amplification and Sequencing}

We extracted total genomic DNA from the preserved tissue samples using the Animal Genomic DNA Kit (BioBasic Canada Inc.), DNeasy Blood \& Tissue Kit (Qiagen), or the phenol-chloroform standard protocol (Sambrook \& Russell 2006). We amplified the large subunit ribosomal RNA (16S) and cytochrome oxidase subunit I (COI) mitochondrial genes. The primers 16Sar and 16Sbr (Palumbi et al. 1991) were used for $16 \mathrm{~S}$ and $\operatorname{dgLCO}$ and $\mathrm{dgHCO}$ (Meyer 2003) for COI. The PCR amplifications were performed using a total volume of $15 \mu \mathrm{L}$, which contained $1 \mu \mathrm{L}$ DNA template $(c .50 \mathrm{ng} /$ $\mu \mathrm{L}$ ), $0.75 \mathrm{U}$ Taq polymerase (Amplificasa ${ }^{\circledR}$, Biotecnologias Moleculares), 1X PCR buffer with $1.5 \mathrm{~mm} \mathrm{MgCl}_{2}, 0.2 \mathrm{mM}$ deoxynucleotide triphosphates (dNTPs), and 0.3-0.5 $\mu \mathrm{M}$ forward and reverse primers. The PCR conditions are as follow: 16S, an initial cycle of $5 \mathrm{~min}$ at $94^{\circ} \mathrm{C}$, followed by 35 cycles of $45 \mathrm{~s}$ at $94^{\circ} \mathrm{C}, 30 \mathrm{~s}$ at 50 or $55^{\circ} \mathrm{C}, 45$ or $120 \mathrm{~s}$ at $72^{\circ} \mathrm{C}$, plus a final cycle of $3 \mathrm{~min}$ at $72^{\circ} \mathrm{C}$; COI, an initial cycle of $2 \mathrm{~min}$ at $94^{\circ} \mathrm{C}$, followed by 35 cycles of $30 \mathrm{~s}$ at $94^{\circ} \mathrm{C}$, $30 \mathrm{~s}$ at $50^{\circ} \mathrm{C}, 45 \mathrm{~s}$ at $72^{\circ} \mathrm{C}$, plus a final cycle of 3 min at $72^{\circ} \mathrm{C}$. PCR products were cleaned with ExoSap-IT (USB Corporation) and sequenced in both directions using the original amplification primers and BigDye termination reaction chemistry (Applied Biosystems). The cycle- 


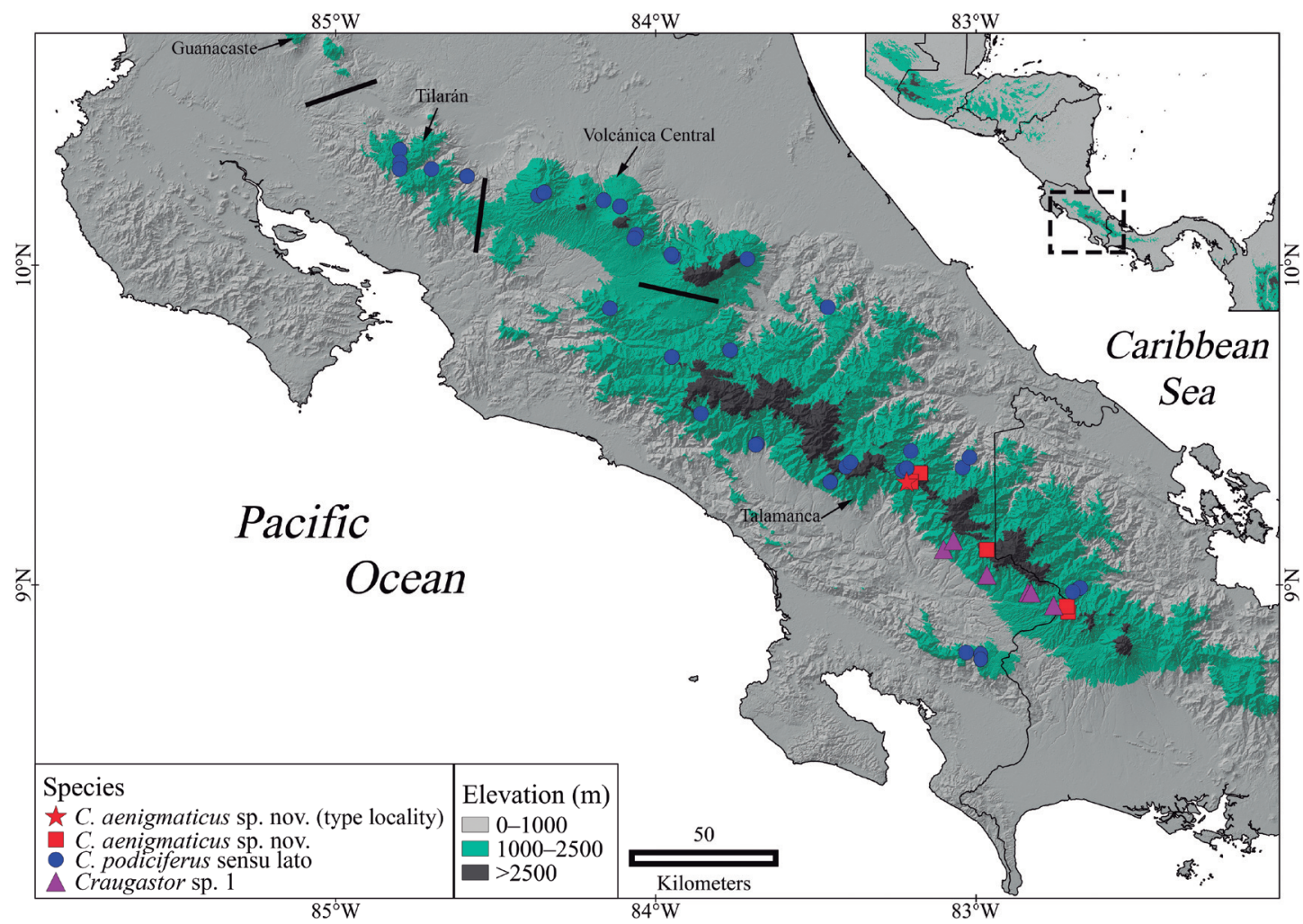

Figure 1. Map showing the known populations of Craugastor aenigmaticus sp. nov. (red star = type locality) in the Cordillera de Talamanca, and the populations of C. podiciferus used in our molecular analysis. Solid (black) lines depict the geographical limits between each mountain range.

sequencing products were column-purified with Sephadex G-50 (GE Healthcare) and run on an ABI 3500xL Genetic Analyzer (Applied Biosystems). Consensus sequences for each individual were constructed using SEQUENCHER 5.3 (Genes Codes Corp.).

\section{Phylogenetic Analyses}

The sequences obtained were compared to those available in GenBank for the Craugastor podiciferus Species Group and sequences of $C$. gollmeri (Peters, 1863) were used as the outgroup. See Appendix I for the list of DNA voucher and GenBank Accession numbers used in this study. Sequence alignments were performed using the MUSCLE 3.7 software (Edgar 2004) with default parameters and trimmed to the point at which a majority of taxa had sequence data. We partitioned the sequence data by gene, and further partitioned COI by codon position. We used PartitionFinder v1.1.1 (Lanfear et al. 2012) and the Bayesian Information Criterion (BIC) to select the best partition scheme and the best model of sequence evolution for each partition. We used a single set of branch-lengths across all partitions (branchlengths $=$ linked); the search of the best partition scheme was using a heuristic search $($ scheme $=$ greedy $)$. We defined, a priori, four partitions: one for $16 \mathrm{~S}$ and three for COI (one for each codon). 
We performed analyses using both the maximum likelihood (ML) and Bayesian analyses (BA). For ML we used Garli 2.01 (Zwickl 2006), with 10 search replicates with the following default setting values changed: streefname $=$ random, attachmentspertaxon $=24$, genthreshfortopoterm $=100000$, significanttopochange $=$ 0.00001 . For bootstrapping, we ran 1000 replicates with the previous settings with the following changes: genthreshfortopoterm = 10000 , significanttopochange $=0.01$, treerejectionthreshold $=20$, as suggested in the Garli manual to speed up bootstrapping. The bootstrap consensus tree was performed using Sumtrees (Sukumaran and Holder 2010a) from DendroPy packages Version 4.4.0 (Sukumaran and Holder 2010b). Bayesian phylogenetic analysis was performed using MrBayes 3.2.6 (Ronquist et al. 2012) with the partition scheme and the model of sequence evolution for each partition as selected previously. Two separate analyses were run; each consisted of 20 million generations, sampled every 1000 generations, and four chains with default heating parameters. We examined a time-series plot of the likelihood scores of the cold chain to check stationarity using Tracer 1.6 software (Rambaut et al. 2014). We discarded the first $25 \%$ of trees as burn-in and used the remaining trees to estimate the consensus tree along with the posterior probabilities for each node and each parameter. The ML and Bayesian analyses were run on the CIPRES portal (Miller et al. 2010). Estimates of pairwise evolutionary genetic divergence between species were computed using MEGA7 (Kumar et al. 2016), assuming uncorrected distances based on the Tamura 3-parameter model (Tamura 1992), with rate variation among the sites modeled as a gamma distribution with the shape parameter $=4$ as the default of the software.

\section{Morphometric Analyses}

We performed a morphometric analysis to compare the new species with Craugastor podiciferus because the taxa closely resemble one another and both inhabit the TMR (allopatrically). In addition we compared the new species with a third undescribed species (Craugastor sp.1) because populations of this frog are located nearby ( $5 \mathrm{~km}$ airline distance) (Figure 1). We examined 20 specimens of the new species from four localities, $86 C$. podiciferus from several localities in Costa Rica, and 19 Craugastor sp.1 (Appendix II). Specimens are deposited at UCR. The following morphological measurements were recorded, as described by Savage (2002), Duellman and Lehr (2009), and Arias et al. (2016): snout-vent length (SVL), head length (HL), head width (HW), interorbital distance (IOD), width of upper eyelid (EW), intercanthal distance (IC), internarial distance (IN), upper lip-nostril distance $(\mathrm{TN})$, eye-nostril distance $(\mathrm{E}-\mathrm{N})$, eye diameter (ED), tympanum diameter (TY), ulna length (UL), hand length (HaL), lengths of the Fingers I (F1) and III (F3), femur length (FL), tibia length (TL), tarsus length (TaL), foot length (FoL), and lengths of the Toes III (T3) and V (T5). Measurements were taken with dial calipers and were rounded to the nearest $0.1 \mathrm{~mm}$.

We transformed the morphometric data using the method of Lleonart et al. (2000) to avoid allometric effects relative to the differences in the size and shape between species and between individuals. In this method, a logarithmic transformation of the continuous variables is performed to reduce the extreme values. All transformed variables are used in the allometric transformation by means of equation $\mathrm{Y}_{i}^{*}=\mathrm{Y}_{\mathrm{i}}$ $\left(\mathrm{X}_{0} / \mathrm{X}_{\mathrm{i}}\right)^{b}$, where $\mathrm{Y}_{\mathrm{i}}^{*}$ is the value of each of the dependent variable corrected for size and shape; $\mathrm{Y}_{i}$ is the value of each of the dependent morphometric variable; $\mathrm{X}_{0}$ is the average of the SVL variable for all populations; $X_{i}$ is the SVL value for each individual; and $b$ is the regression line intercept with the $\mathrm{Y}$-axis resulting from the regression of each dependent variable with $X_{0}$. The intercept is used as an allometric transformation factor and is unique for each 
variable. The additional proportions reported here include: EW/IOD, IOD/HW, TY/ED, EN/ ED, ED/HL, IC/HL, IN/EN, IN/TN, FL/TL, TL/ TaL, TaL/FoL, T3/FoL, T5/FoL, UL/HaL, F1/ $\mathrm{HaL}$, and $\mathrm{F} 3 / \mathrm{HaL}$. The sex of individuals was determined by gonadal morphology. Specimens with opaque seminal vesicles were assumed to be adult males, and those with developed oviducts were assumed to be adult females. The general terminology for the morphological characteristics follows that of Duellman and Lehr (2009). We adopted Savage's (2002) usage of the term "supernumerary tubercles" to refer to the tubercles on the phalanges (between subarticular tubercles); this differs from the tubercles denoted as accessory palmar or plantar tubercles.

We calculated the mean, standard deviation, and range for each morphometric variable without correction. We performed a discriminant analysis to determine whether the morphometric variables were effective to predict the species, using the following variables: EW/IOD, IOD/ HW, TY/ED, EN/ED, ED/HL, IC/HL, IN/EN, IN/TN, FL/TL, TL/TaL, TaL/FoL, T3/FoL, UL/ $\mathrm{HaL}, \mathrm{F} 1 / \mathrm{HaL}$, and F3/HaL. We also conducted a Principal Component Analysis (PCA) to explore the degree of structure within the sample and which variables have more loads in the segregation of groups. All analyses were performed using R v3.3.3 (R Core Team 2017).

\section{Results}

\section{Molecular Data}

The data matrix includes 56 sequences, with a total sequence length of $1222 \mathrm{bp}$, including gaps: 565 bp for $16 \mathrm{~S}$ and $657 \mathrm{bp}$ for COI. Three partition schemes were identified with the following substitution models: GTR $+\mathrm{I}+\mathrm{G}$ for $16 \mathrm{~S}$ and $\mathrm{COI}$ codon position $3, \mathrm{~K} 80+\mathrm{I}+\mathrm{G}$ for COI codon position 1 , and $\mathrm{HKY}+\mathrm{I}$ for $\mathrm{COI}$ codon position 2. Genetic distances between the new species and other members of the Craugastor podiciferus Species Group are of 9.2-18.5\% for
$16 \mathrm{~S}$ and $18.9-24.8 \%$ for COI. Specifically, the new species is separated by a mean-uncorrected genetic distance to $C$. podiciferus of $11.57-$ $16.15 \%$ for $16 \mathrm{~S}$ and $19.16-24.35 \%$ for COI and to Craugastor sp.1 of $12.25-12.9 \%$ in $16 \mathrm{~S}$ and $23.57-24.72 \%$ in COI.

The phylogenies inferred by Garli and MrBayes were mostly congruent (Figure 2), with six well-supported clades. The three most basal clades represent three unnamed species (Craugastor sp.B, Craugastor sp.1, and Craugastor sp.2) that occur in the highlands of the southwestern end of Cordillera de Talamanca. The fourth clade contains the samples from Cerro Hakú, Cerro Utyum, and Cerro Pando at Cordillera de Talamanca (Figure 1). A fifth major clade includes seven species of the $C$. podiciferus Species Group that mainly occur from the lowlands to intermediate elevations from eastern Honduras to central Panama. The sixth major clade is formed by all the samples of C. podiciferus sensu lato that are broadly distributed in the highlands of Costa Rica and western Panama (Figure 1).

The main differences between the ML and Bayesian topologies are in the relationships of Craugastor sp.B, Craugastor sp.1, and Craugastor sp.2 within the phylogeny. Their placement is unresolved in the ML tree, whereas in the Bayesian tree (not shown), Craugastor sp. 1 is the most basal taxon for the entire group. Craugastor sp. 1 + Craugastor sp.B form a clade that is sister to the rest of the species group.

\section{Morphometric Analysis}

Morphometric variation among the species is shown in Table 1. The PCA did not differentiate specimens of the new species from those of Craugastor podiciferus and Craugastor sp.1. The discriminant analysis correctly classified $87.9 \%$ of the specimens to the species, showing a clear separation between the specimens of the new taxon and the specimens referred to $C$. podiciferus and Craugastor sp.1 (Figure 3). 
Craugastor gollmerii AJC1926

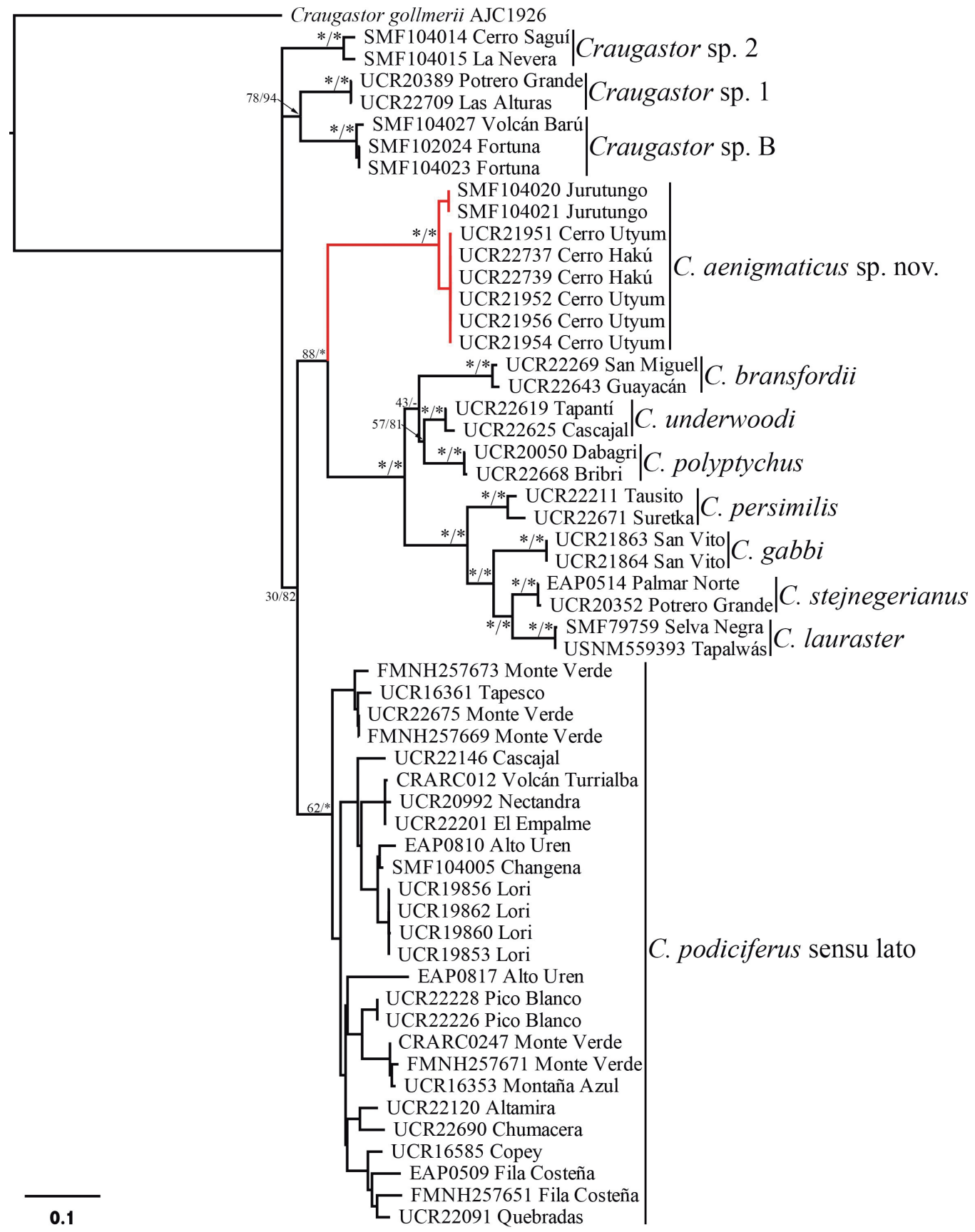

Figure 2. Maximum likelihood phylogeny of Craugastor podiciferus Species Group based on $16 \mathrm{~S}$ and COI mitochondrial DNA genes. Bootstraps proportions are before the slash, and posterior probabilities (multiplied by 100) from MrBayes analysis are following the slash. The scale bar refers to the estimated substitutions per site. The support values of any node within species are not shown. The asterisks represent support of $>95$. 


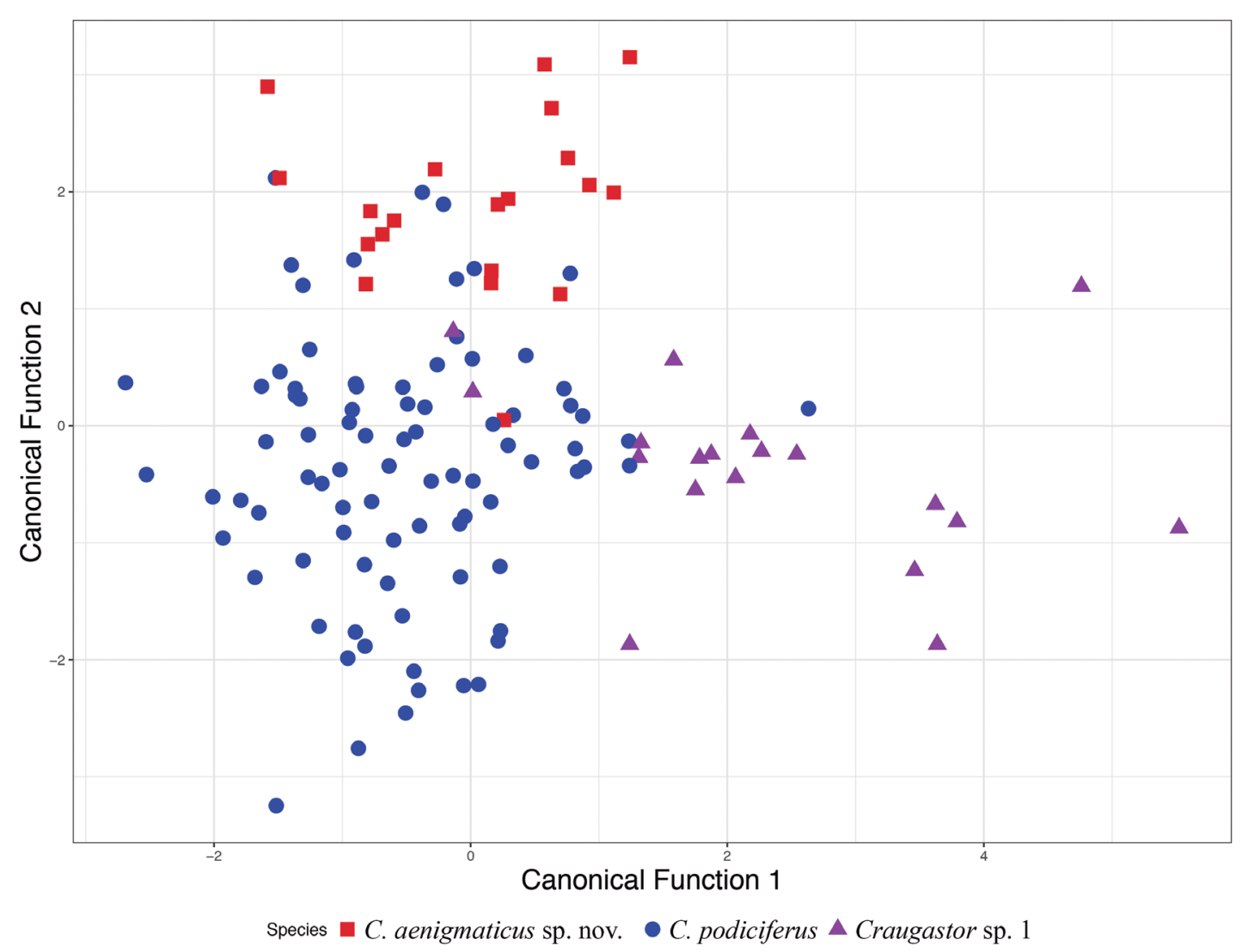

Figure 3. Linear discriminant analysis showing the morphological separation among the 20 individuals of Craugastor aenigmaticus sp. nov. and the individuals of $C$. podiciferus and Craugastor sp.1.

Craugastor aenigmaticus sp. nov. Montane Dirt Frog

(Figures 4-6)

Holotype.-UCR 22961 (EAP 0762), an adult female from Costa Rica: Provincia de Puntarenas: Cantón de Buenos Aires: Distrito de Buenos Aires: summit of Cerro Arbolado, Parque Internacional La Amistad, (09¹9'12.0" N, 8312'57.6" W; $2600 \mathrm{~m}$ a.s.1.), collected by Erick Arias and Omar Zúñiga on 19 October 2016.

Paratopotypes.-UCR 22957 (EAP 0758), subadult male; UCR 22958 (EAP 0759) and
UCR 22960 (EAP 0761), adult females; UCR 22962 (EAP 0763), subadult female; UCR 22959 (EAP 0760), juvenile; same date as the holotype.

Paratypes.-UCR 21951 (EAP 0303), adult female from Costa Rica: Provincia de Limón: Cantón de Talamanca: Distrito de Telire: Caribbean slopes of Cerro Utyum, Parque Internacional La Amistad, (09²0'56.4" N, 8310'30.0" W; $2700 \mathrm{~m}$ a.s.1.), collected by Erick Arias, Gerardo Chaves, Olmer Cordero, and Omar Zúñiga on 12 July 2013. UCR 22414 (EAP 0490) and UCR 22415 (EAP 0491), adult females, same data as UCR 21951 but collected on 29 March 2013. UCR 22737 (EAP 0674) and 
Table 1. Mean $\pm \mathrm{SD}$ and range (in $\mathrm{mm}$ ) for morphometric variables by species. Abbreviations: SVL, Snout-vent length; HL, head length; HW, head width; IOD, interorbital distance; EW, width of the upper eyelid; IC, intercanthal distance; IN, internarial distance; TN, upper lip-nostril distance; E-N, eye-nostril distance; ED, eye diameter; TY, tympanum diameter; UL, ulna length; HaL, hand length; F1, length of Finger I; F3, length of Finger III; FL, femur length; TL, tibia length; TaL, tarsus length; FoL, foot length; T3, length of Toe III; T5, length of Toe $\mathrm{V}$.

\begin{tabular}{|c|c|c|c|c|c|c|}
\hline \multirow[t]{2}{*}{ Variable } & \multicolumn{2}{|c|}{ Craugastor aenigmaticus sp. nov. } & \multicolumn{2}{|c|}{ Craugastor podiciferus } & \multicolumn{2}{|c|}{ Craugastor sp. 1} \\
\hline & Mean \pm SD & Min-Max & Mean $\pm \mathrm{SD}$ & Min-Max & Mean $\pm \mathrm{SD}$ & Min-Max \\
\hline SVL & $26.38 \pm 9.33$ & $16.10-41.10$ & $24.27 \pm 4.76$ & $15.10-35.10$ & $20.79 \pm 3.94$ & $13.80-26.50$ \\
\hline $\mathrm{HL}$ & $10.65 \pm 3.52$ & $6.20-15.95$ & $9.91 \pm 1.76$ & $6.45-13.60$ & $8.44 \pm 1.47$ & $5.70-10.30$ \\
\hline HW & $10.61 \pm 3.68$ & $6.25-16.50$ & $9.66 \pm 1.88$ & $6.20-14.15$ & $8.22 \pm 1.64$ & $5.60-10.70$ \\
\hline IOD & $3.265 \pm 1.10$ & $1.80-5.55$ & $3.23 \pm 0.53$ & $2.10-4.55$ & $2.74 \pm 0.51$ & $1.80-3.70$ \\
\hline EW & $2.08 \pm 0.70$ & $1.20-3.20$ & $1.80 \pm 0.38$ & $1.15-2.90$ & $1.62 \pm 0.34$ & $1.15-2.10$ \\
\hline IC & $5.20 \pm 1.64$ & $3.25-8.00$ & $5.02 \pm 0.77$ & $3.55-6.95$ & $4.22 \pm 0.73$ & $3.15-5.30$ \\
\hline IN & $3.29 \pm 0.99$ & $2.15-4.85$ & $3.04 \pm 0.51$ & $2.20-4.30$ & $2.57 \pm 0.39$ & $1.95-3.25$ \\
\hline TN & $1.54 \pm 0.46$ & $1.00-2.30$ & $1.25 \pm 0.24$ & $0.90-2.10$ & $1.04 \pm 0.18$ & $0.70-1.25$ \\
\hline EN & $2.59 \pm 0.77$ & $1.55-3.70$ & $2.43 \pm 0.46$ & $1.50-3.60$ & $1.99 \pm 0.42$ & $1.30-2.60$ \\
\hline ED & $3.05 \pm 0.95$ & $2.05-4.90$ & $2.88 \pm 0.49$ & $1.90-3.90$ & $2.46 \pm 0.32$ & $1.90-2.90$ \\
\hline TY & $2.01 \pm 0.73$ & $0.95-3.15$ & $1.75 \pm 0.41$ & $1.00-2.70$ & $1.96 \pm 0.32$ & $1.55-2.95$ \\
\hline UL & $6.08 \pm 2.34$ & $3.10-9.65$ & $5.56 \pm 1.09$ & $3.50-8.20$ & $4.80 \pm 0.99$ & $3.35-6.30$ \\
\hline $\mathrm{HaL}$ & $6.93 \pm 2.57$ & $3.70-11.00$ & $5.83 \pm 1.24$ & $3.55-9.50$ & $5.03 \pm 0.99$ & $3.10-6.55$ \\
\hline $\mathrm{F} 1$ & $2.62 \pm 1.31$ & $1.10-4.85$ & $2.10 \pm 0.55$ & $1.10-3.95$ & $1.93 \pm 0.56$ & $0.90-2.95$ \\
\hline F3 & $4.16 \pm 1.62$ & $2.20-6.50$ & $3.46 \pm 0.79$ & $1.75-6.10$ & $2.97 \pm 0.62$ & $1.80-3.90$ \\
\hline $\mathrm{FL}$ & $14.73 \pm 5.85$ & $7.90-23.00$ & $12.40 \pm 2.80$ & $7.60-20.30$ & $10.67 \pm 1.96$ & $7.05-14.00$ \\
\hline $\mathrm{TL}$ & $16.75 \pm 6.54$ & $8.50-25.85$ & $14.07 \pm 3.04$ & $8.25-22.50$ & $12.25 \pm 2.26$ & $8.25-15.25$ \\
\hline TaL & $9.44 \pm 3.38$ & $5.45-14.25$ & $8.28 \pm 1.66$ & 5.10-12.85 & $7.36 \pm 1.35$ & $5.10-9.30$ \\
\hline FoL & $14.87 \pm 5.76$ & $7.95-23.50$ & $12.79 \pm 2.75$ & $7.65-20.15$ & $10.94 \pm 2.24$ & $7.05-14.15$ \\
\hline T3 & $5.40 \pm 2.32$ & 2.05-9.70 & $4.46 \pm 0.99$ & $2.60-7.25$ & $3.79 \pm 0.77$ & $2.45-5.05$ \\
\hline T5 & $4.27 \pm 1.82$ & $1.70-7.00$ & $3.67 \pm 0.95$ & $1.90-6.70$ & $2.99 \pm 0.58$ & $1.90-3.80$ \\
\hline EW/IOD & $0.64 \pm 0.07$ & $0.46-0.75$ & $0.56 \pm 0.09$ & $0.38-0.89$ & $0.59 \pm 0.08$ & $0.44-0.76$ \\
\hline EN/ED & $0.86 \pm 0.11$ & $0.67-1.02$ & $0.84 \pm 0.07$ & $0.64-1.04$ & $0.81 \pm 0.10$ & $0.63-0.98$ \\
\hline $\mathrm{ED} / \mathrm{HL}$ & $0.29 \pm 0.03$ & $0.25-0.35$ & $0.29 \pm 0.02$ & $0.25-0.33$ & $0.29 \pm 0.02$ & $0.26-0.33$ \\
\hline IOD/HW & $0.31 \pm 0.03$ & $0.27-0.38$ & $0.34 \pm 0.03$ & $0.27-0.43$ & $0.34 \pm 0.02$ & $0.30-0.38$ \\
\hline TY/ED & $0.66 \pm 0.15$ & $0.45-1.03$ & $0.61 \pm 0.10$ & $0.41-1.00$ & $0.81 \pm 0.17$ & $0.62-1.34$ \\
\hline $\mathrm{IC} / \mathrm{HL}$ & $0.49 \pm 0.02$ & $0.43-0.53$ & $0.51 \pm 0.03$ & $0.45-0.61$ & $0.50 \pm 0.05$ & $0.36-0.58$ \\
\hline IN/EN & $1.27 \pm 0.12$ & $1.03-1.55$ & $1.26 \pm 0.11$ & $0.95-1.53$ & $1.31 \pm 0.16$ & $1.10-1.62$ \\
\hline IN/TN & $2.14 \pm 0.13$ & $1.94-2.44$ & $2.45 \pm 0.20$ & $1.90-2.94$ & $2.50 \pm 0.22$ & $2.21-3.00$ \\
\hline $\mathrm{FL} / \mathrm{TL}$ & $0.88 \pm 0.03$ & $0.80-0.94$ & $0.88 \pm 0.05$ & $0.54-0.96$ & $0.87 \pm 0.03$ & $0.79-0.92$ \\
\hline $\mathrm{TL} / \mathrm{TaL}$ & $1.76 \pm 0.10$ & $1.51-1.94$ & $1.70 \pm 0.07$ & $1.48-1.83$ & $1.67 \pm 0.07$ & $1.58-1.91$ \\
\hline TaL/FoL & $0.64 \pm 0.04$ & $0.58-0.77$ & $0.65 \pm 0.03$ & $0.58-0.73$ & $0.68 \pm 0.03$ & $0.59-0.72$ \\
\hline T3/FoL & $0.36 \pm 0.04$ & $0.24-0.46$ & $0.35 \pm 0.02$ & $0.30-0.39$ & $0.35 \pm 0.01$ & $0.32-0.36$ \\
\hline T5/FoL & $0.28 \pm 0.04$ & $0.18-0.34$ & $0.28 \pm 0.02$ & $0.22-0.38$ & $0.27 \pm 0.02$ & $0.22-0.31$ \\
\hline UL/HaL & $0.88 \pm 0.05$ & $0.77-0.95$ & $0.96 \pm 0.06$ & $0.81-1.16$ & $0.96 \pm 0.08$ & $0.82-1.11$ \\
\hline F1/HaL & $0.36 \pm 0.06$ & $0.27-0.47$ & $0.36 \pm 0.04$ & $0.24-0.43$ & $0.38 \pm 0.05$ & $0.29-0.46$ \\
\hline F3/HaL & $0.60 \pm 0.02$ & $0.56-0.64$ & $0.59 \pm 0.04$ & $0.49-0.67$ & $0.59 \pm 0.04$ & $0.51-0.68$ \\
\hline
\end{tabular}


UCR 22747 (EAP 0684), adult males from Costa Rica: Provincia de Puntarenas: Cantón de Buenos Aires: Distrito de Buenos Aires: summit of Cerro Hakú, Parque Internacional La Amistad, (09¹9'19.2” N, 83¹2'10.8” W; 2660 m a.s.l.), collected by Erick Arias and Omar Zúñiga on 28 December 2015.

Group assignment.-Assigned to the genus Craugastor based on possessing the following characters: differentiated tympanum; absence of cranial crest; and Toe III longer than Toe V. Assigned to the $C$. podiciferus Species Group based on having a narrow head (HW/SVL = $36.1-43.64 \%$ ) and a rugose dorsum, but lacking inner tarsal folds, webbing between the toes, nuptial pads, and vocal slits.

Diagnosis. - The combination of the following characteristics distinguish Craugastor aenigmaticus from its congeners (Figure 4 and 5): (1) skin on venter smooth, but with large granules laterally; (2) vocal slits absent; (3) nuptial pads absent; (4) toes lacking webbing; (5) heels lacking enlarged calcar tubercle, but can have one to three small tubercles or granules on heels; (6) supernumerary, accessory palmar, and plantar tubercles absent; and (7) unique coloration consisting of a dark brown, olive, olive-brown or dark violet-brown dorsal ground color, violet-brown to blackish brown venter with white to white-bluish pigment forming blotches, dark brown palmar surface in adults with prominent white folds between subarticular tubercles, and in some specimens, white bones apparent through the skin (Figure $6 C)$.

Comparisons with other species.-Craugastor aenigmaticus differs from all the other craugastorids of isthmian Central America except for those in the $C$. podiciferus Species Group by having a narrow head (HW 36.1$43.64 \%$ SVL) and toes that lack webbing. Craugastor aenigmaticus differs from other members of the $C$. podiciferus Species Group by having the following characteristics (condition

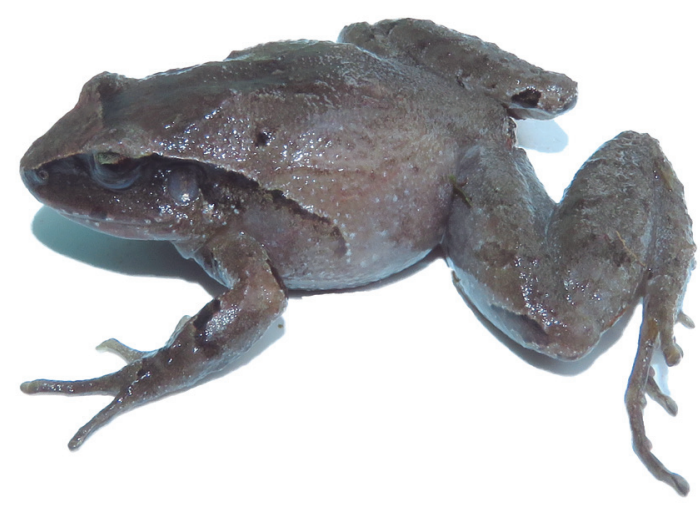

Figure 4. Craugastor aenigmaticus sp. nov. Photograph taken by EA.

for $C$. aenigmaticus in parentheses). In $C$. bransfordii (Cope, 1886), C. gabbi Arias, Chaves, Crawford, and Parra-Olea, 2016, C. lauraster (Savage, McCranie, and Espinal, 1996), C. persimilis (Barbour, 1926), C. polyptychus (Cope, 1886), C. stejnegerianus (Cope, 1893), and C. underwoodi (Boulenger, 1896): (1) the venter is cream (olive-brown in life, and dark brown in ethanol); (2) the venter, as well as the midline, is completely areolate to tuberculate (smooth, at least in the midline in $C$. aenigmaticus); and (3) they range in altitude from 0-1600 $\mathrm{m}$ a.s.l. (range 2330-2700 m a.s.1.). Craugastor jota (Lynch, 1980) differs from $C$. aenigmaticus by having a prominent calcar tubercle on the heel (evident calcar tubercle absent, although some individuals have one to three small tubercles). Craugastor podiciferus differs from $C$. aenigmaticus by: (1) having a prominent calcar tubercle on the heel (Figure 7) (evident calcar tubercle absent although some individuals could have one to three small tubercles); (2) venter yellow, orange, grayish or olive in adults (adults with venter violet-brown with white blotches); and (3) by lack of white prominent folds between subarticular tubercles on hands of adults (prominent white folds between the subarticular tubercles on the hands of adults) (Figure 6D). 


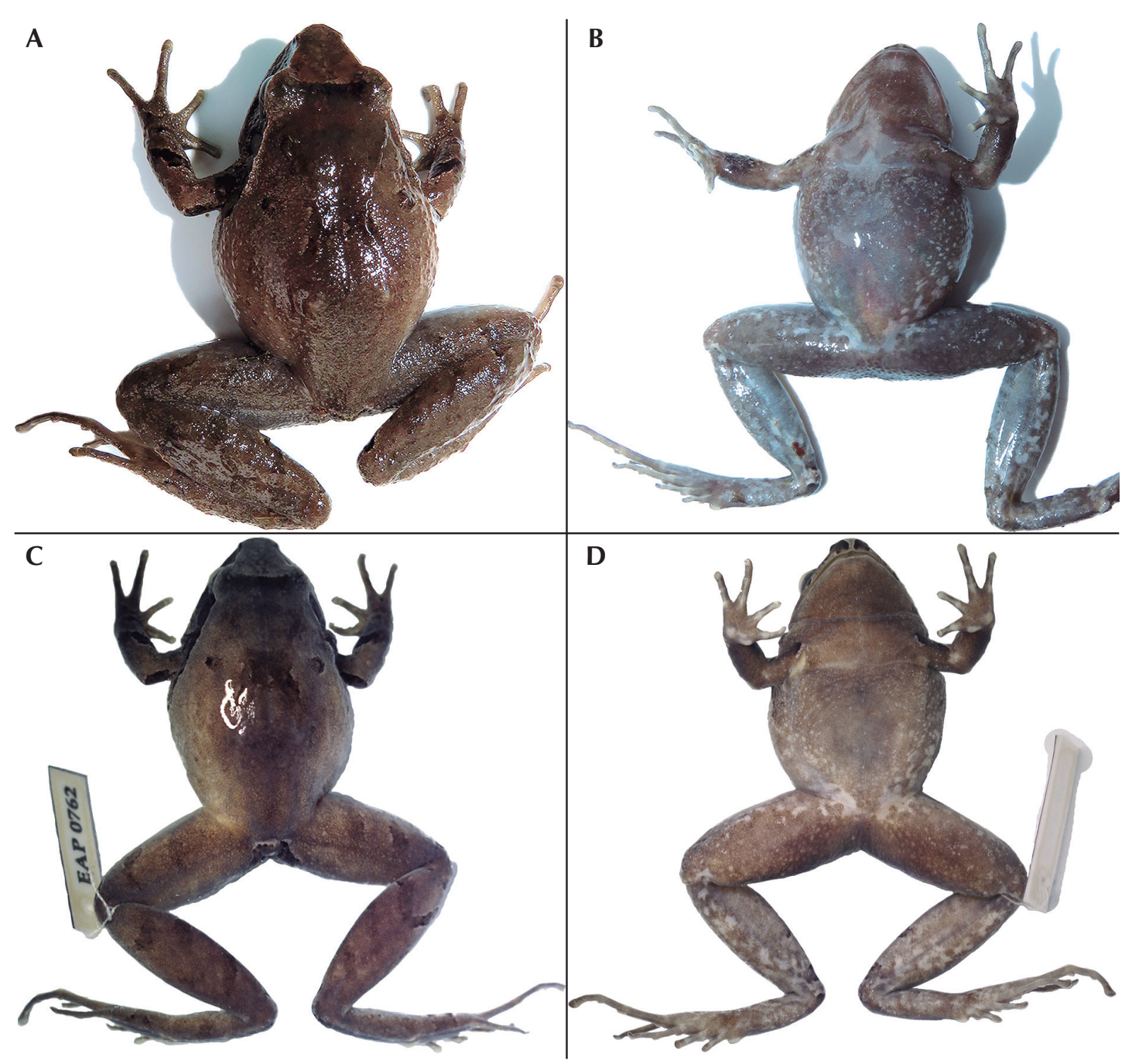

Figure 5. Dorsal (right) and ventral (left) color in life (above) and in ethanol (below) of the holotype (UCR 22961) of Craugastor aenigmaticus sp. nov. Photographs taken by EA.

Description of the holotype.-Adult female, $\mathrm{SVL}=40.1 \mathrm{~mm}$ (Figures 4, 5). Head relatively narrow, width $=41.15 \%$ SVL; snout subovoid in dorsal view, rounded in profile; snout relatively long $(\mathrm{HL}=15.6 \mathrm{~mm}, 38.9 \% \mathrm{SL})$, with nostrils directed laterally; in ventral view, tip of snout protruding markedly beyond edge of lower lip. Internarial area convex (IN $4.85 \mathrm{~mm}$ ); canthus rostralis rounded; intercanthal area flat (IC $=8.0$ $\mathrm{mm}$ ); loreal region slightly concave; vomerine teeth transverse, in two fascicles well behind the choanae. Tongue round, lacking a distinct posterior notch; teeth absent; choanae moderately large, rounded on posterior half, but flat on anterior half, hemispherical; vocal slits absent. Eye moderate $(\mathrm{EW}=92.75 \% \quad \mathrm{E}-\mathrm{N})$, not 
protruding beyond dorsal and ventral outline of head, directed laterally. Tympanum distinct, round, and covered by skin; tympanic annulus prominent, round, small (54.12\% of ED). Skin on all dorsal and lateral surfaces of head moderately granular. Upper eyelid granular, without superciliar or supraocular tubercles. Postrictal tubercles fused forming short ridge posteroventral to tympanum. Skin on dorsum and limbs weakly granular. Skin of chest smooth,

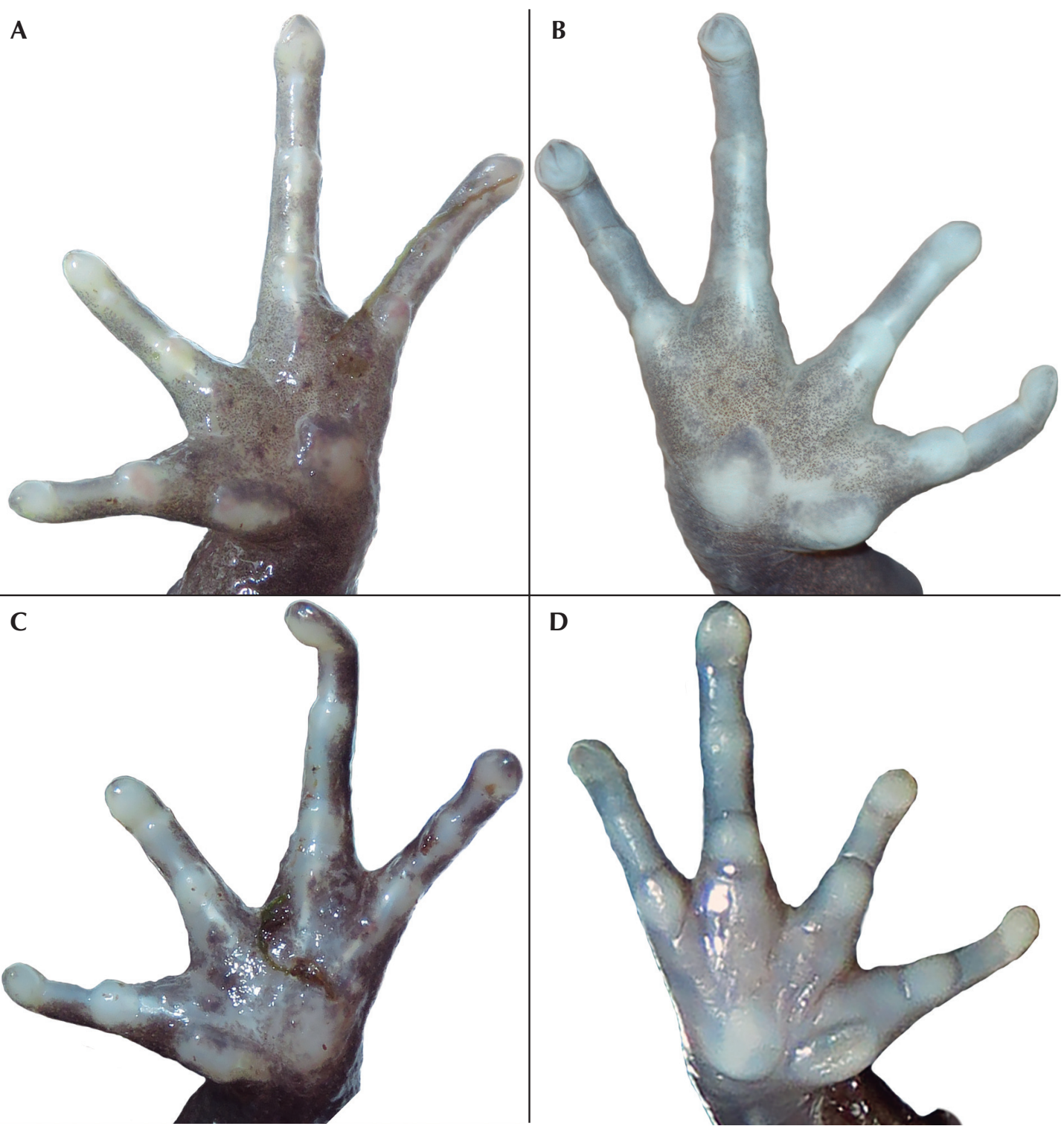

Figure 6. Variation of the ventral views of the hands for comparison. (A) Craugastor aenigmaticus sp. nov. holotype in life (UCR 22961); (B) holotype (UCR 22961) in ethanol; (C) paratopotype (UCR 22958); (D) C. podiciferus. Photographs taken by EA. 

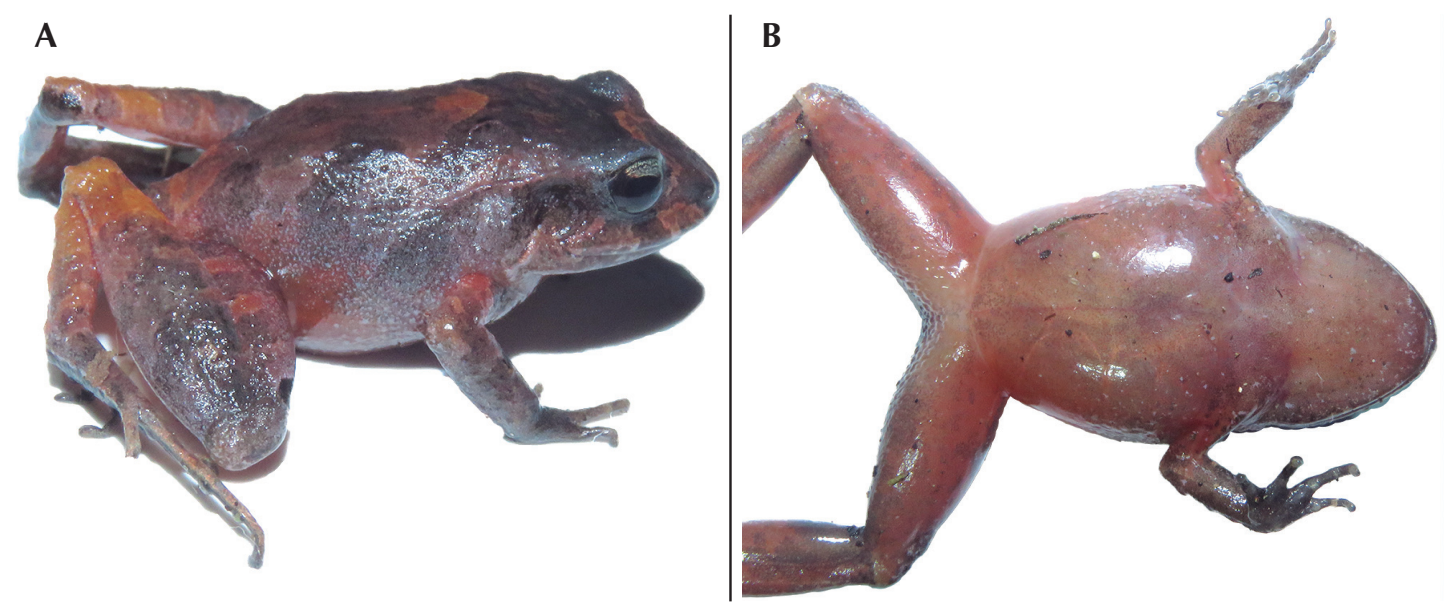

Figure 7. Dorsal (A) and ventral (B) color in life views of Craugastor podiciferus (EAP 0803), for comparison. Note the enlarged calcar tubercle and coloration on dorsum and venter. Photographs taken by EA.

venter smooth and encroached on laterally by low granules; ventral surfaces of thighs smooth to weakly granular; skin of groin and ventral surfaces of arms and lower legs nearly smooth. Flanks areolate, especially along the anteroventral flank region; skin on chin smooth. A pair of complete hourglass-shaped dorsal ridges present between posterior margin of eye and sacrum. Pair of supratympanic folds extending from posterior margin of eye, above tympanum, bifurcating at the axillary level, one fold continues laterally and other continues to the venter. Discoidal fold complete.

Forelimb relatively short and robust; fingers moderately long and slim without lateral fringes. Discs absent; fingers with grooves; tips of fingers unexpanded, rounded in dorsal view; pads ovoid. Proximal subarticular tubercles indistinct. Supernumerary tubercles absent; accessory palmar tubercles absent; distal subarticular tubercles rounded in basal outline, flattened, and globular in profile; thenar tubercle ovoid, flattened, palmar tubercle rounded, flattened; thenar tubercle much smaller than palmar. Ulnar tubercles and fold absent. Fingers are not webbed.
Legs relatively long and robust; heel granular but lacking enlarged tubercles. Discs absent; toes with grooves; tips of toes unexpanded, lanceolate in dorsal view; pads triangular. Supernumerary tubercles absent; plantar tubercles absent; subarticular tubercles ovoid in basal outline, flattened, and globular in profile; inner metatarsal tubercle elongate, globular; outer metatarsal tubercle rounded, barely discernible, flattened; outer metatarsal tubercle much smaller than inner; inner tarsal fold absent; toes are not webbed. Cloacal opening directed posteriorly at midlevel of thighs.

Coloration of the holotype in life.-Dorsal ground color is uniform dark brown, but with two dark spots on the scapular region (Figure 4). A dark interorbital mark is present, lying just posterior to an adjacent paler area. Dorsal surfaces of the legs and arms with dark bars. The surfaces below the canthus rostralis and the supratympanic fold, from the snout to the axilla, are darker (forming a type of mask); the dark pigment of the mask continues posteriorly bordering the supratympanic fold. The upper lip has dark bars with white pigment in form of 
faded bars. The flanks are the same color as dorsum, but with white pigment in form of small spots. Ventral surfaces of the body and legs are violet-brown with bluish-white pigment in the form of blotches; ventral surface of tibia-tarsus grayish; ventral surface of the throat violetbrown is relatively uniform, slightly paler than the venter (Figure 5). The palmar surface of the hands with violet coloration, especially on thenar, palmar, and proximal subarticular tubercles; the fingers are whitish, with a white prominent fold between subarticular tubercles (Figure 6A).

Coloration of the holotype in ethanol.-After 2 years in ethanol $(70 \%)$, the overall dark brown dorsum has changed little from its color in life. The violet-brown on ventral surfaces of the body and legs has faded to dark brown and the bluishwhite blotches have changed to light brown. The overall patterns of the blotches and other markings on the holotype have remained identical to those that were observed while alive.

Measurements of holotype ( $\mathrm{mm})$.- - SL 40.1; HL 15.6; HW 16.5; IOD 4.65; EW 3.2; IC 8.0; IN 4.85; TN 2.3; EN 3.45; ED 4.25; TY 2.3; UL 9.65; HaL 10.25; F1 4.85; F3 6.5; FL 22.65; TL 25.85; TaL 14.25; FoL 23.5; T3 8.1; T5 7.0. Measurements in related percentages: EW/IOD 68.82\%; IOD/HW 28.18\%; TY/ED 54.12\%; EN/ ED 81.12\%; ED/HL 27.24\%; IC/HL 51.28\%; IN/EN 140.58\%; IN/TN 210.87\%; FL/TL 87.62\%; TL/TaL 181.40\%; TaL/FoL 60.64\%; T3/FoL 34.47\%; T5/FoL 29.79\%; UL/HaL 94.15\%; F1/HaL 47.32\%; F3/HaL 63.42\%.

Variation.-Morphometric variation is summarized in Table 1. Craugastor aenigmaticus has a relatively high level of intraspecific polymorphisms (Figure 8). The skin on venter ranges from almost completely smooth to heavily areolate, but always with a smooth midline. Some frogs have supraocular tubercles; additionally, some individuals have two postrictal tubercles that are not fused. The palmar tubercle is heart shaped in some specimens, but ovoid in others; the proximal subarticular tubercles are not visible in some specimens. In the adult male, UCR 22747, an accessory palmar tubercle is visible. In some specimens, the heel is areolate; in others one to three small tubercles are visible. Some specimens have flattened subarticular tubercles, whereas others have projecting subarticular tubercles. Some individuals have globular subarticular tubercles in profile, whereas others have obtuse subarticular tubercles. UCR 21951 and UCR 22734 have a pattern of dark brown lateral stripes on a pale brown background (Figure 8E); UCR 21956 has an olive-green dorsum (Figure 8F). The mask is absent in some specimens. The throat is a uniform cream coloration in some frogs, whereas it is uniform violet-brown, heavily mottled, or uniformly dark brown in others. The venter usually is darkbrown or grayish in coloration, but in some individuals, especially in juveniles, it is cream (Figure 8D). The juveniles have light brown arms in contrast to the dark brown dorsum (Figure 8C). The palmar surfaces of the hands in adults usually are dark brown with prominent white folds between subarticular tubercles, but in some frogs, the white bones are visible beneath the skin; in juveniles, the palmar surfaces are dark brown or cream.

Habitat and natural history notes.-Craugastor aenigmaticus inhabits the montane rainforest of the Cordillera de Talamanca (Holdridge 1967, Bolaños et al. 2005), which has a short dry season (1 or $2 \mathrm{mo}$ ), annual precipitation ranging between 2200 and $4500 \mathrm{~mm}$, and annual temperatures ranging from $6-12^{\circ} \mathrm{C}$. The type locality (Cerro Arbolado) and the other known localities consist of primary forest dominated by oak trees (genus Quercus L.) that are abundantly covered with bryophytes and epiphytes (Figure 9). The forest floor is covered by a thick layer of leaf litter and other types of decomposing organic material. Little is known about the natural history of $C$. aenigmaticus, but it is important to note that the species was abundant 

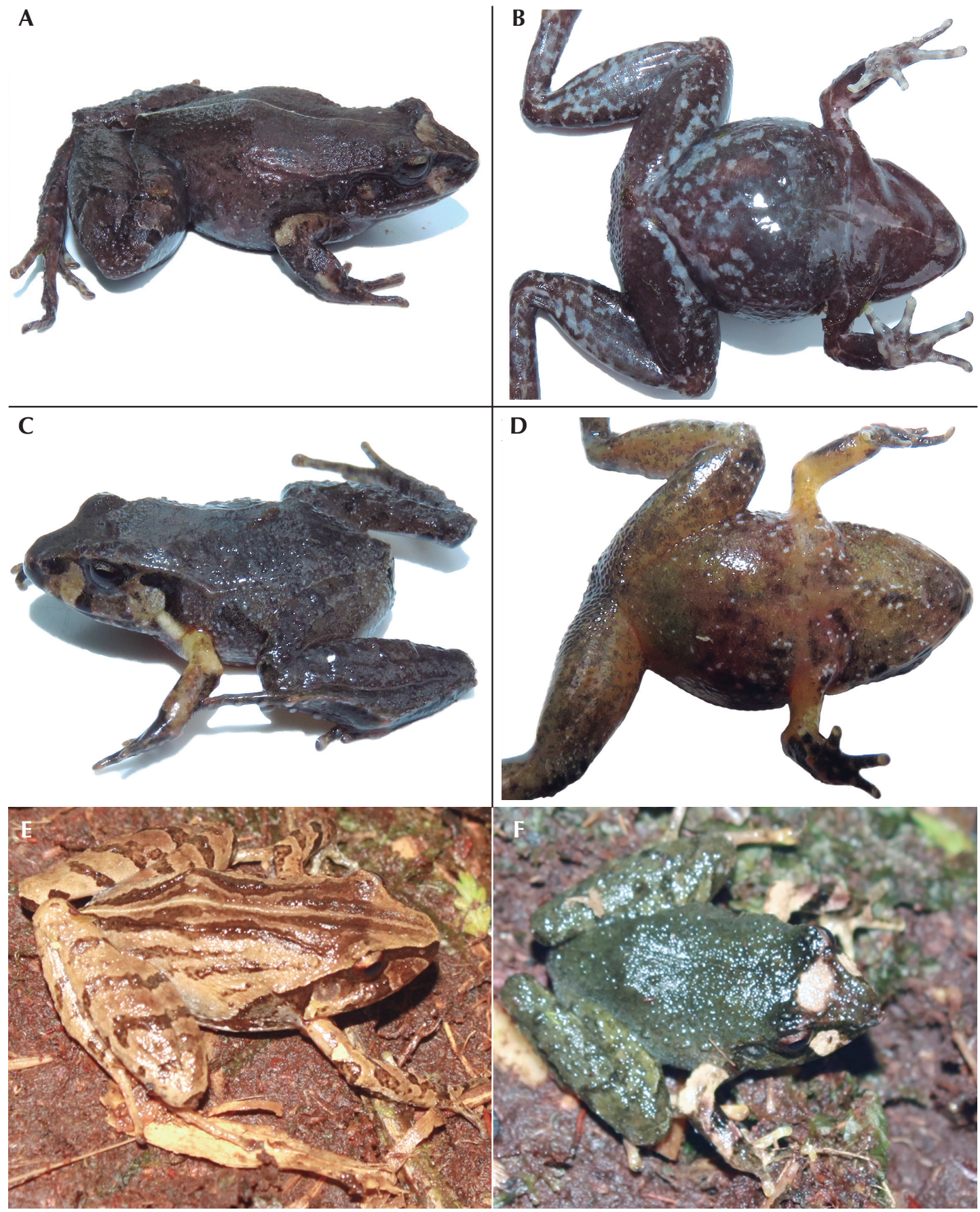

Figure 8. Variation on dorsum and venter of Craugastor aenigmaticus sp. nov. (A, B) Paratopotype UCR 22958, adult female; (C, D) paratopotype UCR 22959, juvenile; (E) paratype UCR 21951, adult female; (F) UCR 21956, juvenile. Photographs taken by EA. 


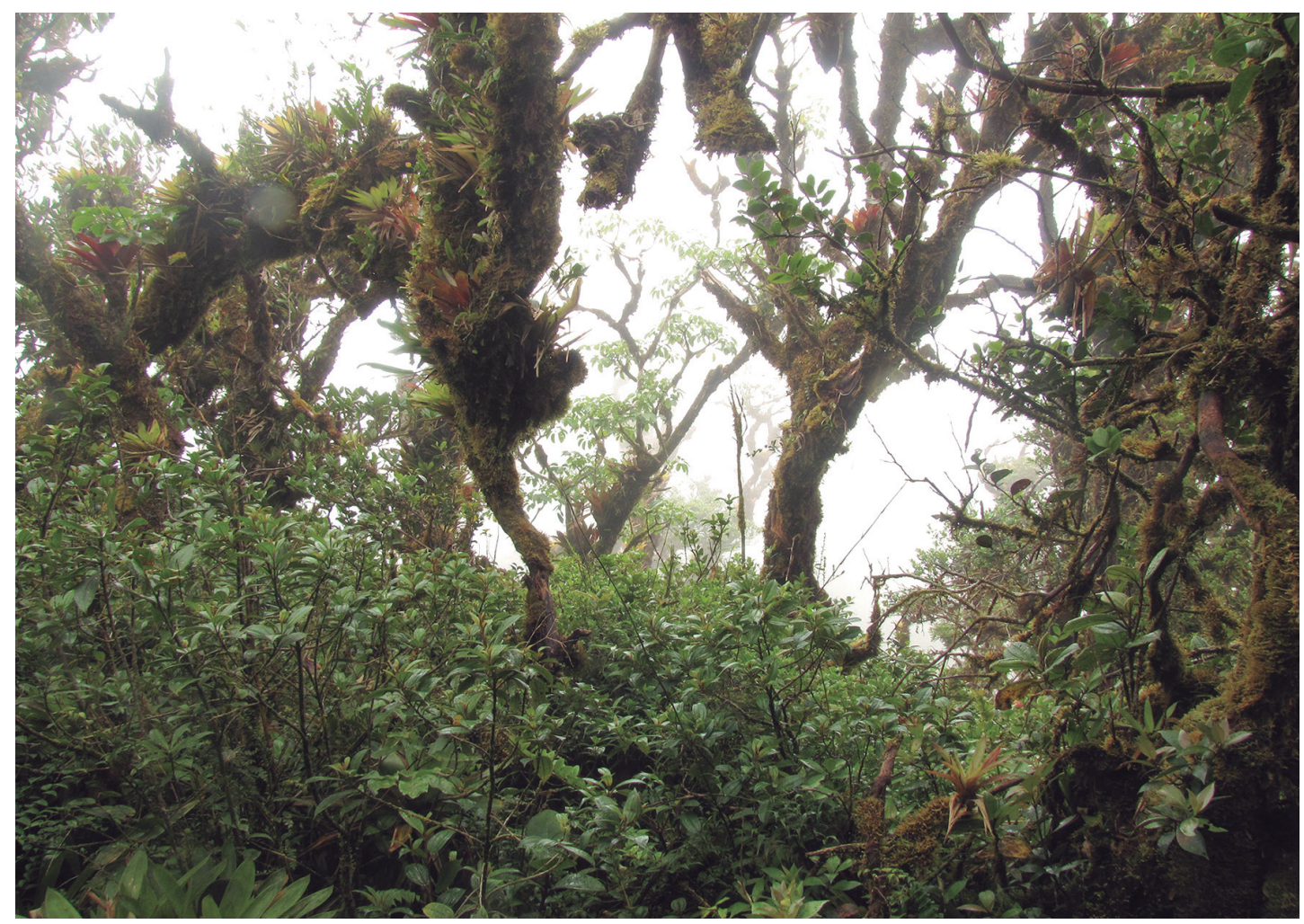

Figure 9. Cloud forest at type locality of Craugastor aenigmaticus sp. nov., summit of Cerro Arbolado at $2600 \mathrm{~m}$ a.s.I. Photograph taken by Omar Becerra Soria.

during our fieldwork in the months of April and July 2013, December 2015, and October 2016. During December 2015 and October 2016, gravid females were observed. Juveniles were observed during all the periods of fieldwork; the smallest size recorded was with a SVL of 16.1 mm. All specimens of $C$. aenigmaticus collected were discovered as they were jumping on the forest floor. We did not record any vocalization that we could attribute to $C$. aenigmaticus, though we think that the frog may vocalize. Craugastor aenigmaticus is sympatric with Diasporus ventrimaculatus in Cerro Arbolado, Cerro Hakú, on the Caribbean slopes of Cerro Utyum, and Valle del Silencio, which is the type locality of D. ventrimaculatus.
Distribution.-Craugastor aenigmaticus is restricted to the summit of Cerro Arbolado, Cerro Hakú, Caribbean slopes of Cerro Utyum, Valle del Silencio, and Caribbean slopes of Cerro Pando (Figure 1). The altitudinal range of this taxon is 2330-2700 $\mathrm{m}$ a.s.l. The species occurs in primary forest; and the populations on Cerro Arbolado, Cerro Hakú, Cerro Utyum, and Valle del Silencio are within the La Amistad International Park and that on Cerro Pando is within the Zona Protectora Las Tablas. The distribution of $C$. aenigmaticus is fragmented along a line of $\sim 80 \mathrm{~km}$. We did not find this species during fieldwork carried out on Cerro Kamuk and Cerro Echandi. More fieldwork is required to assess the range of this species more 
accurately. Given that this species is found at Cerro Pando, which is on the Costa Rica-Panama border, C. aenigmaticus is recognized as having a distribution within southeastern Costa Rica and at least for now, marginally into Panama.

Etymology.-The specific name is derived from the Latin word for enigmatic. We propose this name in light of the taxonomic confusion surrounding this species. Craugastor aenigmaticus was first collected in 2009 but was erroneously identified as $C$. podiciferus because of its great morphological resemblance to the latter, and its close proximity to the type locality of $C$. podiciferus. However, based on molecular data, we confirmed that this taxon is highly divergent genetically from other species in the $C$. podiciferus Species Group and represents a new species.

\section{Discussion}

With the recognition of Craugastor aenigmaticus, the $C$. podiciferus Species Group now comprises 10 species, all of which are endemic to Costa Rica and western Panama (Savage 2002, AmphibiaWeb 2018). However, the diversity within the $C$. podiciferus Species Group is underestimated and several species remain unnamed (Streicher et al. 2009). The high genetic divergence between $C$. aenigmaticus and all other members of the $C$. podiciferus Species Group strongly supports the distinctiveness of $C$. aenigmaticus. The abovementioned genetic distances are greater than those suggested by Fouquet et al. (2007) for recognizing new taxa of Neotropical frogs, which is $3 \% 16 \mathrm{~S}$ divergence as threshold to define candidate species. However, it is important to point out that although not closely related, $C$. aenigmaticus and $C$. podiciferus are morphologically similar. Furthermore, unlike other members of the group, both of these species inhabit the montane rainforest, although C. podiciferus is not restricted to it.
The montane rainforest of the Cordillera de Talamanca is naturally fragmented in two relatively large patches (Bolaños et al. 2005). One extends from Cerro Vueltas to Cerro Dúrika and the other from Cerro Arbolado to Cerro Echandi, and both are separated by a depression (2300 $\mathrm{m}$ a.s.1.). Craugastor aenigmaticus inhabits the patch that extends from Cerro Arbolado to Cerro Echandi. Bolitoglossa kamuk, B. pygmaea, B. robinsoni, and B. splendida are endemic to the same patch of montane rainforest. Craugastor aenigmaticus occurs in sympatry with $D$. ventrimaculatus in four localities, with the former only being known from one additional locality (Cerro Pando).

The restricted distribution of Craugastor aenigmaticus to montane rainforest highlights the importance of this habitat as center of diversification and endemism, and suggests that the highlands of the Cordillera de Talamanca have had an important role in the process of speciation, possibly in association with climatic fluctuations (Savage 2002, Streicher et al. 2009). At least eight amphibians are restricted to montane rainforest in Cordillera de Talamanca (Savage 2002, AmphibiaWeb 2018), a habitat that was naturally reduced along the last 2 million years and that is fragmented (Foster 2001).

Further studies are needed to help us resolve the phylogenetic relationships of Craugastor aenigmaticus within the $C$. podiciferus Species Group and to evaluate the biological significance of the high genetic distances that exist within the group. Additionally, it is important to continue inventory work in the montane rainforest to justify the need to protect the flora and fauna of this life zone, much of which may remain unknown.

\section{Acknowledgments}

We thank Laura Márquez-Valdelamar and Andrea Jiménez-Marín for their laboratory assistance; Federico Bolaños for the use of specimens from the Museo de Zoología of the Universidad de Costa Rica; Omar Zúñiga and 
Olmer Cordero provided valuable assistance in the field during the expeditions; Omar Becerra Soria provided photographs of the type locality. We are especially grateful to Brian Kubicki for reviewing an early draft of the manuscript and for his numerous comments and suggestions, which greatly improved its quality. We thank Jaime Bertoluci and Linda Trueb whose comments greatly improved this manuscript. EA thanks the Posgrado en Ciencias Biológicas for support of this study, the CONACyT for the students grant (CVU/Becario) 626946/330343, and the Programa de Innovación y Capital Humano para la Competitividad PINN-MICITT for the students grant (PED-0339-15-2). Laboratory work was funded by grant from PAPIIT-UNAM (IN203617) to GP-O. Fieldwork was partially supported by the National Geography Society (Grant number W-346-14). We acknowledge the Costa Rican Ministry of Environment and Energy (MINAE) for providing the corresponding scientific collecting permits for this expedition (SINAC-SE-GAS-PI-R 0072013 and 59-2015).

\section{References}

AmphibiaWeb. 2018. Information on Amphibian Biology and Conservation. Electronic Database accessible at http://amphibiaweb.org/. Berkeley, California, USA. Captured on 04 June 2018.

Arias, E. and F. Bolaños. 2014. A checklist of the amphibians and reptiles of San Isidro de Dota, Reserva Forestal Los Santos, Costa Rica. Checklist 10: 870-877.

Arias, E. and G. Chaves. 2014. 140 years after William M. Gabbs's climb to Cerro Pico Blanco. Mesoamerican Herpetology 1: 176-180.

Arias, E., G. Chaves, A. J. Crawford, and G. Parra-Olea. 2016. A new species of the Craugastor podiciferus species group (Anura: Craugastoridae) from the premontane forest of southwestern Costa Rica. Zootaxa 4132: $347-363$.

Bolaños, R., V. Watson, and J. Tosi. 2005. Mapa Ecológico de Costa Rica (Zonas de Vida), Según el Sistema de Clasificación de Zonas de Vida del Mundo de L. R. Holdridge, Escala 1:750 000. Vol. 214. San José. Centro Científico Tropical.
Boza-Oviedo, E., S. M. Rovito, G. Chaves, A. GarcíaRodríguez, L. G. Artavia, F. Bolaños, and D. B. Wake. 2012. Salamanders from the eastern Cordillera de Talamanca, Costa Rica, with descriptions of five new species (Plethodontidae: Bolitoglossa, Nototriton, and Oedipina) and natural history notes from recent expeditions. Zootaxa 3309: 36-61.

Campbell, J. A. 1999. Distribution patterns of amphibians in Middle America. Pp. 111-210 in W. E. Duellman (ed.), Patterns of Distribution of Amphibians: A Global Perspective. Baltimore and London. The Johns Hopkins University Press.

Cope, E. D. 1875. On the Batrachia and Reptilia of Costa Rica. Journal Academy of Natural Sciences 2: 93-157.

Crawford, A. J. and E. N. Smith. 2005. Cenozoic biogeography and evolution in direct-developing frogs of Central America (Leptodactylidae: Eleutherodactylus) as inferred from a phylogenetic analysis of nuclear and mitochondrial genes. Molecular Phylogenetics and Evolution 35: 536-555.

Edgar, R. C. 2004. MUSCLE: multiple sequence alignment with high accuracy and high throughput. Nucleic Acids Research 32: 1792-1797.

Duellman, W. E. and E. Lehr. 2009. Terrestrial-Breeding Frogs (Strabomantidae) in Peru. Münster. Natur- und Tier-Verlag. 382 pp.

Foster, P. 2001. The potential negative impacts of global climate change on tropical montane cloud forest. EarthScience Reviews 55: 73-106.

Fouquet, A., A. Gilles, M. Vences, C. Marty, M. Blanc, and N. J. Gemmell. 2007. Underestimation of species richness in Neotropical frogs revealed by mtDNA analyses. PLOS ONE 2: e1109.

Frost, D. R. 2018. Amphibian Species of the World: an Online Reference. Version 6.0. Electronic Database accessible at: http://research.amnh.org/herpetology/ amphibia/index.html. American Museum of Natural History, New York, USA. Captured on 04 June 2018.

Gutiérrez-García, T. A. and E. Vázquez-Domínguez. 2013. Consensus between genes and stones in the biogeographic and evolutionary history of Central America. Quaternary Research 79: 311-324.

Hedges, S. B., W. E. Duellman, and M. P. Heinicke. 2008. New World direct-developing frogs (Anura: Terrarana): molecular phylogeny, classification, biogeography, and conservation. Zootaxa 1737: 1-182.

Holdridge, L. R. 1967. Life Zone Ecology. San José. Tropical Science Center. 206 pp. 
Kubicki, B. 2008. Amphibian diversity in Guayacán, Limón province, Costa Rica. Brenesia 69: 35-42.

Kumar, S., G. Stecher, and K. Tamura. 2016. MEGA7: Molecular Evolutionary Genetics Analysis version 7.0 for bigger datasets. Molecular Biology and Evolution 33: 1870-1874.

Lanfear, R., B. Calcott, S. Y. Ho, and S. Guindon. 2012. PartitionFinder: combined selection of partitioning schemes and substitution models for phylogenetic analyses. Molecular Biology and Evolution 29: 1695 1701.

Lleonart, J., J. Salat, and G. J. Torres. 2000. Removing allometric effects of body size in morphological analysis. Journal of Theoretical Biology 205: 85-93.

Meyer, C. P. 2003. Molecular systematics of cowries (Gastropoda: Cypraeidae) and diversification patterns in the tropics. Biological Journal of the Linnean Society 79: 401-459.

Miller, M. A., W. Pfeiffer, and T. Schwartz. 2010. Creating the CIPRES Science Gateway for inference of large phylogenetic trees. Proceedings of the Gateway Computing Environments Workshop (GCE) 14 November 2010: 1-8.

Olson, D. M., E. Dinerstein, E. D. Wikramanayake, N. D. Burgess, G. V. N. Powell, E. C. Underwood, J. A. D'amico, I. Itoua, H. E. Strand, J. C. Morrison, C. J. Loucks, T. F. Allnutt, T. H. Ricketts, Y. Kura, J. F. Lamoreux, W. W. Wettengel, P. Hedao, and K. R. Kassem. 2001. Terrestrial ecoregions of the world: a new map of life on earth. BioScience 51: 933-938.

Palumbi, S., A. Martin, S. Romano, W. O. McMillan, L. Stice, and G. Grabowski. 1991. The simple fool's guide to PCR, version 2.0. Honolulu. Special Publication, Department of Zoology and Kewalo Marine Laboratory, University of Hawaii. 43 pp.

R Core Team. 2017. R: a Language and Environment for Statistical Computing. R Foundation for Statistical Computing, Vienna, Austria. Version 3.3.3. URL: http:// www.R-project.org.

Rambaut, A., M. A. Suchard, W. Xie, and A. J. Drummond. 2014. Tracer. Version 1.6.1. URL: http://beast.bio.ed. ac.uk/Tracer.
Ronquist, F., M. Teslenko, P. Van Der Mark, D. L. Ayres, A. Darling, S. Höhna, B. Larget, L. Liu, M. Suchard, and J. P. Huelsenbeck. 2012. MrBayes 3.2: efficient Bayesian phylogenetic inference and model choice across a large model space. Systematic Biology 61: 539-542.

Sambrook, J. and D. W. Russell. 2006. Purification of nucleic acids by extraction with phenol: chloroform. Cold Spring Harbor Protocols 2006: pdb-prot4455.

Santos-Barrera, G., J. Pacheco, F. Mendoza-Quijano, F. Bolaños, G. Chaves, and G. C. Daily. 2008. Diversity, natural history and conservation of amphibians and reptiles from the San Vito Region, southwestern Costa Rica. Revista de Biología Tropical 56: 755-778.

Savage, J. M. 2002. The Amphibians and Reptiles of Costa Rica: A Herpetofauna Between Two Continents, Between Two Seas. Chicago. The University of Chicago Press. 934 pp.

Sukumaran, J. and M. T. Holder. 2010a. SumTrees: Phylogenetic Tree Summarization. Version 4.4.0. URL: https://github.com/jeetsukumaran/DendroPy.

Sukumaran, J. and M. T. Holder. 2010b. DendroPy: a Python library for phylogenetic computing. Bioinformatics 26: 1569-1571.

Streicher, J. W., A. J. Crawford, and C. W. Edwards. 2009. Multilocus molecular phylogenetic analysis of the montane Craugastor podiciferus species complex (Anura: Craugastoridae) in Isthmian Central America. Molecular Phylogenetics and Evolution 53: 620-630.

Tamura, K. 1992. Estimation of the number of nucleotide substitutions when there are strong transitiontransversion and $\mathrm{G}+\mathrm{C}$-content biases. Molecular Biology and Evolution 9: 678-687.

Zwickl, D. J. 2006. Genetic algorithm approaches for the phylogenetic analysis of large biological sequence datasets under the maximum likelihood criterion. Unpublished Ph.D. Dissertation. The University of Texas, USA.

Editor: Jaime Bertoluci 
Appendix I. Institutional voucher numbers, locality information, and GenBank accession numbers for the specimens used in the molecular phylogenetic analyses. Museum codes follow those of Frost (2018), with the addition of CRARC in reference to the Costa Rica Amphibian Research Center private collection and EAP denotes field numbers of Erick Arias.

\begin{tabular}{|c|c|c|c|c|c|c|}
\hline \multirow{2}{*}{ Species } & \multirow{2}{*}{$\begin{array}{l}\text { Institutional } \\
\text { vouchers }\end{array}$} & \multirow{2}{*}{ Collection locality } & \multirow{2}{*}{$\begin{array}{l}\text { Geographic } \\
\text { coordinates }\end{array}$} & \multirow{2}{*}{$\begin{array}{c}\text { Elevation } \\
\text { (m a.s.l.) }\end{array}$} & \multicolumn{2}{|c|}{ GenBank Number } \\
\hline & & & & & $16 \mathrm{~S}$ & $\mathrm{COI}$ \\
\hline C. aenigmaticus sp. nov. & SMF: 104020 & $\begin{array}{l}\text { Jurutungo, Changuinola, } \\
\text { Bocas del Toro, PA }\end{array}$ & $8^{\circ} 54^{\prime} \mathrm{N}, 82^{\circ} 42^{\prime} \mathrm{W}$ & 2388 & MK211615 & MK211577 \\
\hline C. aenigmaticus sp. nov. & SMF: 104021 & $\begin{array}{c}\text { Jurutungo, Changuinola, } \\
\text { Bocas del Toro, PA }\end{array}$ & $8^{\circ} 55^{\prime} \mathrm{N}, 82^{\circ} 42^{\prime} \mathrm{W}$ & 2330 & MK211621 & - \\
\hline C. aenigmaticus sp. nov. & UCR: 21951 & $\begin{array}{c}\text { Cerro Utyum, Talamanca, } \\
\text { Limón, CR }\end{array}$ & $9^{\circ} 20^{\prime} \mathrm{N}, 83^{\circ} 10^{\prime} \mathrm{W}$ & 2700 & MK211616 & MK211578 \\
\hline C. aenigmaticus sp. nov. & UCR: 21952 & $\begin{array}{c}\text { Cerro Utyum, Talamanca, } \\
\text { Limón, CR }\end{array}$ & $9^{\circ} 20^{\prime} \mathrm{N}, 83^{\circ} 10^{\prime} \mathrm{W}$ & 2690 & MK211618 & - \\
\hline C. aenigmaticus sp. nov. & UCR: 21954 & $\begin{array}{c}\text { Cerro Utyum, Talamanca, } \\
\text { Limón, CR }\end{array}$ & $9^{\circ} 20^{\prime} \mathrm{N}, 83^{\circ} 10^{\prime} \mathrm{W}$ & 2627 & MK211620 & - \\
\hline C. aenigmaticus sp. nov. & UCR: 21956 & $\begin{array}{c}\text { Cerro Utyum, Talamanca, } \\
\text { Limón, CR }\end{array}$ & $9^{\circ} 20^{\prime} \mathrm{N}, 83^{\circ} 10^{\prime} \mathrm{W}$ & 2690 & MK211619 & - \\
\hline C. aenigmaticus sp. nov. & UCR: 22737 & $\begin{array}{l}\text { Cerro Hakú, Buenos Aires, } \\
\text { Puntarenas, CR }\end{array}$ & $9^{\circ} 19^{\prime} \mathrm{N}, 83^{\circ} 12^{\prime} \mathrm{W}$ & 2660 & MK211617 & MK211579 \\
\hline C. aenigmaticus sp. nov. & UCR: 22739 & $\begin{array}{c}\text { Cerro Hakú, Buenos Aires, } \\
\text { Puntarenas, CR }\end{array}$ & $9^{\circ} 19^{\prime} \mathrm{N}, 83^{\circ} 12^{\prime} \mathrm{W}$ & 2660 & MK211622 & - \\
\hline C. bransfordii & UCR: 22269 & $\begin{array}{l}\text { San Miguel, Alajuela, } \\
\text { Alajuela, CR }\end{array}$ & $10^{\circ} 18^{\prime} \mathrm{N}, 84^{\circ} 10^{\prime} \mathrm{W}$ & 466 & KT950295 & MK211571 \\
\hline C. bransfordii & UCR: 22643 & $\begin{array}{l}\text { Guayacán, Siquirres, } \\
\text { Limón, CR }\end{array}$ & $10^{\circ} 03^{\prime} \mathrm{N}, 83^{\circ} 32^{\prime} \mathrm{W}$ & 537 & MK211610 & MK211572 \\
\hline C. gabbi & UCR: 21863 & $\begin{array}{c}\text { Fila Costeña, Coto Brus, } \\
\text { Puntarenas, CR }\end{array}$ & $8^{\circ} 47^{\prime} \mathrm{N}, 82^{\circ} 57^{\prime} \mathrm{W}$ & 1200 & KT950271 & MK211567 \\
\hline C. gabbi & UCR: 21864 & $\begin{array}{l}\text { Fila Costeña, Coto Brus, } \\
\text { Puntarenas, CR }\end{array}$ & $8^{\circ} 47^{\prime} \mathrm{N}, 82^{\circ} 57^{\prime} \mathrm{W}$ & 1200 & KT950272 & MK211568 \\
\hline C. lauraster & SMF: 79759 & $\begin{array}{c}\text { Selva Negra, Matagalpa, } \\
\text { Matagalpa, NI }\end{array}$ & $12^{\circ} 59^{\prime} \mathrm{N}, 85^{\circ} 54^{\prime} \mathrm{W}$ & 1300 & MK211608 & MK211565 \\
\hline C. lauraster & USNM: 559393 & $\begin{array}{l}\text { Bodega del Río, Tapalwás, } \\
\text { Gracias a Dios, HN }\end{array}$ & $14^{\circ} 55^{\prime} \mathrm{N}, 84^{\circ} 32^{\prime} \mathrm{W}$ & 150 & KU323364 & MK211566 \\
\hline C. persimilis & UCR: 22211 & $\begin{array}{c}\text { Tausito, Paraiso, Cartago, } \\
\text { CR }\end{array}$ & $9^{\circ} 47^{\prime} \mathrm{N}, 83^{\circ} 45^{\prime} \mathrm{W}$ & 1050 & KT950293 & MK211570 \\
\hline C. persimilis & UCR: 22671 & $\begin{array}{l}\text { Suretka, Talamanca, } \\
\text { Limón, CR }\end{array}$ & $9^{\circ} 34^{\prime} \mathrm{N}, 82^{\circ} 56^{\prime} \mathrm{W}$ & 121 & MK211609 & MK211569 \\
\hline C. podiciferus s.l. & CRARC: 012 & $\begin{array}{c}\text { Volcán Turrialba, Turrialba, } \\
\text { Cartago, CR }\end{array}$ & $10^{\circ} 01^{\prime} \mathrm{N}, 83^{\circ} 42^{\prime} \mathrm{W}$ & 2250 & MK211633 & MK211589 \\
\hline C. podiciferus s.l. & CRARC: 247 & $\begin{array}{l}\text { Monte Verde, Tilarán, } \\
\text { Guanacaste, CR }\end{array}$ & $10^{\circ} 21^{\prime} \mathrm{N}, 84^{\circ} 48^{\prime} \mathrm{W}$ & 1470 & MK211645 & - \\
\hline C. podiciferus s.l. & EAP: 509 & $\begin{array}{l}\text { Fila Costeña, Golfito, } \\
\text { Puntarenas, CR }\end{array}$ & $8^{\circ} 47^{\prime} \mathrm{N}, 83^{\circ} 01^{\prime} \mathrm{W}$ & 1546 & - & MK211605 \\
\hline C. podiciferus s.l. & EAP: 810 & $\begin{array}{l}\text { Alto Uren, Talamanca, } \\
\text { Limón, CR }\end{array}$ & $9^{\circ} 21^{\prime} \mathrm{N}, 83^{\circ} 02^{\prime} \mathrm{W}$ & 1860 & MK211640 & MK211596 \\
\hline C. podiciferus s.l. & EAP: 817 & $\begin{array}{l}\text { Alto Uren, Talamanca, } \\
\text { Limón, CR }\end{array}$ & $9^{\circ} 23^{\prime} \mathrm{N}, 83^{\circ} 01^{\prime} \mathrm{W}$ & 1500 & MK211630 & MK211586 \\
\hline
\end{tabular}


Appendix I. Continued.

\begin{tabular}{|c|c|c|c|c|c|c|}
\hline \multirow{2}{*}{ Species } & \multirow{2}{*}{$\begin{array}{c}\text { Institutional } \\
\text { vouchers }\end{array}$} & \multirow{2}{*}{ Collection locality } & \multirow{2}{*}{$\begin{array}{l}\text { Geographic } \\
\text { coordinates }\end{array}$} & \multirow{2}{*}{$\begin{array}{l}\text { Elevation } \\
\text { (m a.s.l.) }\end{array}$} & \multicolumn{2}{|c|}{ GenBank Number } \\
\hline & & & & & $16 \mathrm{~S}$ & $\mathrm{COI}$ \\
\hline C. podiciferus s.l. & FMNH: 257651 & $\begin{array}{l}\text { Fila Costeña, Coto Brus, } \\
\text { Puntarenas, CR }\end{array}$ & $8^{\circ} 47^{\prime} \mathrm{N}, 82^{\circ} 59^{\prime} \mathrm{W}$ & 1350 & EF562367 & - \\
\hline C. podiciferus s.l. & FMNH: 257669 & $\begin{array}{c}\text { Monte Verde, San Ramón, } \\
\text { Alajuela, CR }\end{array}$ & $10^{\circ} 18^{\prime} \mathrm{N}, 84^{\circ} 47^{\prime} \mathrm{W}$ & 1500 & EF562372 & MK211598 \\
\hline C. podiciferus s.l. & FMNH: 257671 & $\begin{array}{c}\text { Monte Verde, San Ramón, } \\
\text { Alajuela, CR }\end{array}$ & $10^{\circ} 18^{\prime} \mathrm{N}, 84^{\circ} 47^{\prime} \mathrm{W}$ & 1500 & EF562374 & MK211599 \\
\hline C. podiciferus s.l. & FMNH: 257673 & $\begin{array}{c}\text { Monte Verde, San Ramón, } \\
\text { Alajuela, CR }\end{array}$ & $10^{\circ} 18^{\prime} \mathrm{N}, 84^{\circ} 47^{\prime} \mathrm{W}$ & 1500 & EF562343 & MK211603 \\
\hline C. podiciferus s.l. & SMF: 104005 & $\begin{array}{l}\text { Changena, Changuinola, } \\
\text { Bocas del Toro, PA }\end{array}$ & $8^{\circ} 59^{\prime} \mathrm{N}, 82^{\circ} 40^{\prime} \mathrm{W}$ & 1766 & MK211641 & MK211597 \\
\hline C. podiciferus s.l. & UCR: 16353 & $\begin{array}{c}\text { Montaña Azul, Sarapiquí, } \\
\text { Heredia, CR }\end{array}$ & $10^{\circ} 12^{\prime} \mathrm{N}, 84^{\circ} 09^{\prime} \mathrm{W}$ & 1500 & EF562349 & MK211602 \\
\hline C. podiciferus s.l. & UCR: 16361 & $\begin{array}{c}\text { Tapesco, Alfaro Ruiz, } \\
\text { Alajuela, CR }\end{array}$ & $10^{\circ} 13^{\prime} \mathrm{N}, 84^{\circ} 22^{\prime} \mathrm{W}$ & 1930 & EF562371 & - \\
\hline C. podiciferus s.l. & UCR: 16585 & Copey, Dota, San José, CR & $9^{\circ} 32^{\prime} \mathrm{N}, 83^{\circ} 51^{\prime} \mathrm{W}$ & 1400 & MK211647 & - \\
\hline C. podiciferus s.l. & UCR: 19853 & $\begin{array}{l}\text { Lori, Talamanca, Limón, } \\
\text { CR }\end{array}$ & $9^{\circ} 21^{\prime} \mathrm{N}, 83^{\circ} 13^{\prime} \mathrm{W}$ & 1817 & MK211639 & MK211595 \\
\hline C. podiciferus s.l. & UCR: 19856 & $\begin{array}{l}\text { Lori, Talamanca, Limón, } \\
\text { CR }\end{array}$ & $9^{\circ} 21^{\prime} \mathrm{N}, 83^{\circ} 13^{\prime} \mathrm{W}$ & 1817 & MK211637 & MK211593 \\
\hline C. podiciferus s.l. & UCR: 19860 & $\begin{array}{l}\text { Lori, Talamanca, Limón, } \\
\text { CR }\end{array}$ & $9^{\circ} 21^{\prime} \mathrm{N}, 83^{\circ} 12^{\prime} \mathrm{W}$ & 2108 & MK211636 & MK211592 \\
\hline C. podiciferus s.l. & UCR: 19862 & $\begin{array}{l}\text { Lori, Talamanca, Limón, } \\
\text { CR }\end{array}$ & $9^{\circ} 21^{\prime} \mathrm{N}, 83^{\circ} 12^{\prime} \mathrm{W}$ & 2108 & MK211638 & MK211594 \\
\hline C. podiciferus s.l. & UCR: 20992 & $\begin{array}{c}\text { Nectandra, Alfaro Ruiz, } \\
\text { Alajuela, CR }\end{array}$ & $10^{\circ} 13^{\prime} \mathrm{N}, 84^{\circ} 20^{\prime} \mathrm{W}$ & 2143 & MK211632 & MK211588 \\
\hline C. podiciferus s.l. & UCR: 22091 & $\begin{array}{l}\text { Quebradas, Pérez Zeledón, } \\
\text { San José, CR }\end{array}$ & $9^{\circ} 26^{\prime} \mathrm{N}, 83^{\circ} 40^{\prime} \mathrm{W}$ & 1488 & MK211646 & MK211604 \\
\hline C. podiciferus s.l. & UCR: 22120 & $\begin{array}{l}\text { Altamira, Buenos Aires, } \\
\text { Puntarenas, CR }\end{array}$ & $9^{\circ} 19^{\prime} \mathrm{N}, 83^{\circ} 27^{\prime} \mathrm{W}$ & 1821 & MK211642 & - \\
\hline C. podiciferus s.l. & UCR: 22146 & $\begin{array}{c}\text { Cascajal, Coronado, San } \\
\text { José, CR }\end{array}$ & $10^{\circ} 01^{\prime} \mathrm{N}, 83^{\circ} 56^{\prime} \mathrm{W}$ & 1700 & MK211635 & MK211591 \\
\hline C. podiciferus s.l. & UCR: 22201 & $\begin{array}{c}\text { El Empalme, El Guarco, } \\
\text { Cartago, CR }\end{array}$ & $9^{\circ} 42^{\prime} \mathrm{N}, 83^{\circ} 56^{\prime} \mathrm{W}$ & 2395 & MK211634 & MK211590 \\
\hline C. podiciferus s.l. & UCR: 22226 & $\begin{array}{c}\text { Pico Blanco, Escazú, San } \\
\text { José, CR }\end{array}$ & $9^{\circ} 51^{\prime} \mathrm{N}, 84^{\circ} 08^{\prime} \mathrm{W}$ & 2242 & MK211644 & MK211601 \\
\hline C. podiciferus s.l. & UCR: 22228 & $\begin{array}{c}\text { Pico Blanco, Escazú, San } \\
\text { José, CR }\end{array}$ & $9^{\circ} 51^{\prime} \mathrm{N}, 84^{\circ} 08^{\prime} \mathrm{W}$ & 2242 & MK211643 & MK211600 \\
\hline C. podiciferus s.l. & UCR: 22675 & $\begin{array}{l}\text { Monte Verde, Puntarenas, } \\
\text { Puntarenas, CR }\end{array}$ & $10^{\circ} 19^{\prime} \mathrm{N}, 84^{\circ} 47^{\prime} \mathrm{W}$ & 1726 & - & MK211606 \\
\hline C. podiciferus s.l. & UCR: 22690 & $\begin{array}{c}\text { Chumacera, Pérez Zeledón, } \\
\text { San José, CR }\end{array}$ & $9^{\circ} 19^{\prime} \mathrm{N}, 83^{\circ} 28^{\prime} \mathrm{W}$ & 1793 & MK211631 & MK211587 \\
\hline C. polyptychus & UCR: 20050 & $\begin{array}{l}\text { Dabagri, Talamanca, } \\
\text { Limón, CR }\end{array}$ & $9^{\circ} 37^{\prime} \mathrm{N}, 83^{\circ} 16^{\prime} \mathrm{W}$ & 900 & MK211614 & MK211576 \\
\hline C. polyptychus & UCR: 22668 & $\begin{array}{c}\text { Bribri, Talamanca, Limón, } \\
\text { CR }\end{array}$ & $9^{\circ} 36^{\prime} \mathrm{N}, 82^{\circ} 54^{\prime} \mathrm{W}$ & 198 & MK211613 & MK211575 \\
\hline
\end{tabular}


Appendix I. Continued.

\begin{tabular}{|c|c|c|c|c|c|c|}
\hline \multirow{2}{*}{ Species } & \multirow{2}{*}{$\begin{array}{l}\text { Institutional } \\
\text { vouchers }\end{array}$} & \multirow{2}{*}{ Collection locality } & \multirow{2}{*}{$\begin{array}{l}\text { Geographic } \\
\text { coordinates }\end{array}$} & \multirow{2}{*}{$\begin{array}{c}\text { Elevation } \\
\text { (m a.s.l.) }\end{array}$} & \multicolumn{2}{|c|}{ GenBank Number } \\
\hline & & & & & $16 \mathrm{~S}$ & $\mathrm{COI}$ \\
\hline C. stejnegerianus & EAP: 0514 & $\begin{array}{l}\text { Palmar Norte, Osa, } \\
\text { Puntarenas, CR }\end{array}$ & $8^{\circ} 57^{\prime} \mathrm{N}, 83^{\circ} 26^{\prime} \mathrm{W}$ & 45 & MK211607 & MK211563 \\
\hline C. stejnegerianus & UCR: 20352 & $\begin{array}{l}\text { Potrero Grande, Buenos } \\
\text { Aires, Puntarenas, CR }\end{array}$ & $9^{\circ} 05^{\prime} \mathrm{N}, 83^{\circ} 06^{\prime} \mathrm{W}$ & 900 & KT950284 & MK211564 \\
\hline C. underwoodi & UCR: 22619 & $\begin{array}{c}\text { Tapantí, Paraíso, Cartago, } \\
\text { CR }\end{array}$ & $9^{\circ} 45^{\prime} \mathrm{N}, 83^{\circ} 46^{\prime} \mathrm{W}$ & 1412 & MK211611 & MK211573 \\
\hline C. underwoodi & UCR: 22625 & $\begin{array}{c}\text { Cascajal, Coronado, San } \\
\text { José, CR }\end{array}$ & $10^{\circ} 01^{\prime} \mathrm{N}, 83^{\circ} 56^{\prime} \mathrm{W}$ & 1708 & MK211612 & MK211574 \\
\hline Craugastor sp.1 & UCR: 20389 & $\begin{array}{l}\text { Potrero Grande, Buenos } \\
\text { Aires, Puntarenas, CR }\end{array}$ & $9^{\circ} 06^{\prime} \mathrm{N}, 83^{\circ} 06^{\prime} \mathrm{W}$ & 1500 & MK211625 & MK211581 \\
\hline Craugastor sp.1 & UCR: 22709 & $\begin{array}{l}\text { Las Alturas, Coto Brus, } \\
\text { Puntarenas, CR }\end{array}$ & $8^{\circ} 58^{\prime} \mathrm{N}, 82^{\circ} 49^{\prime} \mathrm{W}$ & 1980 & MK211626 & MK211582 \\
\hline Craugastor sp. 2 & SMF: 104014 & $\begin{array}{l}\text { Cerro Saguí, Nole Duima, } \\
\text { Ngöbe Buglé, PA }\end{array}$ & $8^{\circ} 33^{\prime} \mathrm{N}, 81^{\circ} 49^{\prime} \mathrm{W}$ & 1762 & MK211623 & - \\
\hline Craugastor sp.2 & SMF: 104015 & $\begin{array}{l}\text { La Nevera, Nole Duima, } \\
\text { Ngöbe Buglé, PA }\end{array}$ & $8^{\circ} 30^{\prime} \mathrm{N}, 81^{\circ} 46^{\prime} \mathrm{W}$ & 1700 & MK211624 & MK211580 \\
\hline Craugastor sp.B & SMF: 102024 & $\begin{array}{c}\text { Fortuna, Gualaca, Chiriquí, } \\
\text { PA }\end{array}$ & $8^{\circ} 40^{\prime} \mathrm{N}, 82^{\circ} 11^{\prime} \mathrm{W}$ & 1730 & MK211627 & MK211583 \\
\hline Craugastor sp.B & SMF: 104023 & $\begin{array}{l}\text { Fortuna, Gualaca, Chiriquí, } \\
\text { PA }\end{array}$ & $8^{\circ} 40^{\prime} \mathrm{N}, 82^{\circ} 12^{\prime} \mathrm{W}$ & 1280 & MK211628 & MK211584 \\
\hline Craugastor sp.B & SMF: 104027 & $\begin{array}{c}\text { Volcán Barú, Bugaba, } \\
\text { Chiriquí, PA }\end{array}$ & $8^{\circ} 50^{\prime} \mathrm{N}, 82^{\circ} 30^{\prime} \mathrm{W}$ & 2134 & MK211629 & MK211585 \\
\hline
\end{tabular}

Appendix II. Specimens used in the morphometric analysis. Museum collection acronyms follow Frost (2018), with the addition of EAP refers to Erick Arias field numbers.

Craugastor aenigmaticus sp. nov. COSTA RICA: Limón: Cerro Utyum, Telire, Talamanca (UCR: 21951-21952, 2241322415); Valle del Silencio, Telire, Talamanca (UCR: 21194, 21931-21932). Puntarenas: Cerro Arbolado and Cerro Hakú, Buenos Aires, Buenos Aires (EAP: 758-763; UCR: 22731-22734, 22737, 22747).

Craugastor podiciferus. COSTA RICA: Alajuela: Poasito, Sabanilla, Alajuela (UCR: 21317-21319); Zarcero, Palmira, Alfaro Ruiz (UCR: 20992-20994); Los Alpes, Piedades Sur, San Ramón (UCR: 13961-13962). Santa María, Aguas Claras, Upala (UCR: 10528). CARTAGo: Coris, Quebradilla, Cartago (UCR: 3490-3491); Empalme, San Isidro, Guarco (UCR: 22200 , 22202, 22204-22205); Tapantí, Orosi, Paraíso (UCR: 11542, 12010, 21708); Vereh, Chirripó, Turrialba (EAP: 748-750). Heredia: San José de la Montaña, Barva (UCR: 21299, 21352); Cerro Chompipe, Varablanca, Heredia (UCR: 18403-18404); La Legua, Varablanca, Heredia (UCR: 17464, 17478); Montaña Azul, Cureña, Sarapiquí (UCR: 16354). Limón: Fila Matama, Matama, Limón (UCR: 20177, 20213); Cerro Pat, Telire, Talamanca (EAP: 0792, 801-803, 807, 810, 814, 817-818); Sabanas Dúrika, Telire, Talamanca (UCR: 21662, 21682, 21825, 21836); Transtalamanca, Telire, Talamanca (UCR: 19849, 19853, 19860, 19870, 19874, 19895, 19933). Puntarenas: Cerro Quemado, Biolley, Buenos Aires (UCR: 21191, 21700); Las Cruces, San Vito, Coto Brus (UCR: 12934, 12936, 13239); Las Tablas, Sabalito, Coto Brus (UCR: 8379, 8381-8382, 10738, 1074710748, 12560); Monte Verde, Puntarenas (UCR: 13646-13647, 17243, 21718, 22674-22676). SAN José: Pico Blanco, San Antonio, Escazú (UCR: 22228); Tinamaste, Barú, Pérez Zeledón (UCR: 14510, 14513, 14518); Quebradas, San Isidro del General, Pérez Zeledón (EAP: 738-740; UCR: 16359-16360, 22606); Chumacera, San Pedro, Pérez Zeledón (EAP: 721-723; UCR: 22119); Cascajal, Vazquez de Coronado (UCR: 16090, 16092, 21918).

Craugastor sp.1. COSTA RICA: Puntarenas: Las Alturas, Pittier, Coto Brus (UCR: 22703-22704, 22709-22710); Tres Colinas, Potrero Grande, Buenos Aires (EAP: 725, 727-729; UCR: 20257-20258, 20389, 20395, 20401, 20411, 20419, 20421, 20423, 20428); road to Las Tablas, Sabalito, Coto Brus (EAP: 0823). 